\title{
Thyrotropin-dependent proliferation of in vitro rat thyroid cell systems
}

\author{
Diego L Medina and Pilar Santisteban \\ Instituto de Investigaciones Biomédicas 'Alberto Sols', Consejo Superior de Investigaciones Científicas y Universidad Autónoma de Madrid, \\ Arturo Duperier 4, E-28029 Madrid, Spain
}

(Correspondence should be addressed to P Santisteban, Instituto de Investigaciones Biomédicas, CSIC-UAM, Arturo Duperier 4, 28029-Madrid, Spain; Email: psantisteban@iib.uam.es)

\begin{abstract}
This review is focused on the most recent knowledge on growth control of rat thyroid cell lines. We analyzed the effect of mitogenic as well as inhibitory agents, but mainly the proliferative effect elicited by thyrotropin (TSH). The classic cAMP-dependent protein kinase (PKA) signal transduction pathway involved in TSH-mediated cell growth is analyzed exhaustively. We have also reviewed new concepts about the participation of other effectors such as small GTPases and phosphatidyl inositol-3-kinase (PI3-K) and the new data about the existence of a cAMP-dependent but PKA-independent pathway. Finally, we give information about TSH induction of cell cycle-related genes, such as G1 cyclins, cyclindependent kinases (CDKs) and CDK inhibitors.
\end{abstract}

European Journal of Endocrinology 143 161-178

\section{Introduction}

The different extracellular signals that activate proliferation in mammalian cells are coordinated with the cell cycle machinery by different transduction pathways. This activation process involves transcriptional and post-transcriptional events that finally overpass the first GTPase-activating protein (GAP) (G1 phase) and initiate DNA synthesis (S phase). Key regulators of G1 progression include the D- and E-type cyclins, which respectively assemble with cyclin-dependent kinases (CDK)-4/6 during G1 or with CDK-2 at the G1-S boundary. The activation of CDKs, by binding to G1 cyclins, promotes the phosphorylation of necessary substrates like retinoblastoma $(\mathrm{Rb})$ protein. In the absence of phosphorylation, $\mathrm{Rb}$ will negatively regulate the activities of transcription factors implicated in cell cycle control like E2F-DP1 heterodimers, which are essential for the G1-S transition. Alternatively, cyclinCDK complexes can be inhibited by two families of cyclin-dependent kinase inhibitors defined by their structural homology and CDK targets. The first family includes the inhibitor kinase (INK) proteins that specifically bind and inhibit CDK4 and CDK6 but not other CDK or cyclins. The INK family includes four proteins with multiple ankyrin repeat sequences: $116^{\text {INK4a }}$ (1), p1 $5^{I N K 4 b}(2), \mathrm{p} 18^{I N K 4 c}(3,4)$, and $19^{I N K 4 d}(4,5)$. This family contrasts with more broadly acting inhibitors, the
Cip/Kip family, whose action affects the activities of E and A cyclin-dependent CDK2 and positively regulates D cyclindependent kinase (6). The Cip/Kip family includes p21 $1^{\text {Cip1 }}$ $(7-12)$, p $27^{\text {Kip } 1}(13,14)$, and p $57^{\text {Kip } 2}(15,16)$, all of which have characteristic motifs that enable them to bind to cyclin as well as to CDK subunits (17-22).

This review is focused on in vitro experimental models of rat thyroid cell lines including the Fisher rat (FRTL-5) (23), the Wistar rat (WRT) (24) and PC C13 (25) cell lines. Although the FRTL-5 cell line is the most frequently used system, all of them retain most of the features of differentiated follicular thyroid cells, such as thyrotropin (TSH)-dependence for growth and function, iodine uptake, and thyroglobulin (Tg) and thyroperoxidase (TPO) gene expression. The simplicity of these systems allows stable transfections and genetic experiments and also explains why they are the preferred models in most of the in vitro studies of thyroid biology.

The second part of this review is focused on the more recent advances in our understanding of the mitogenic effects of TSH, the signal transduction pathways involved in this response, including the role of the Ras superfamily, and its effects on the main cell cyclerelated genes. Thus, classically, binding of TSH to the TSH receptor (TSH-R) stimulates both growth and function of thyroid cells. TSH-R coupled to adenylyl cyclase elevates cAMP levels promoting the activation of cAMP-dependent kinase (PKA) and the consecutive 
phosphorylation of transcription factors such as cAMP response element binding (CREB) proteins. This phosphorylation is required to activate the expression of important genes implicated in normal growth and phenotype differentiation in thyroid cells (26). We have also reviewed the role of the small GTPases involved in TSH-mediated proliferation and found that the classic view summarized above now seems to be more complex. Thus, TSH-mediated proliferation requires Ras activation but not through typical Ras effectors such as Raf-1/ mitogen-activated protein kinase (MAPK). Some evidence indicates that other Ras effectors, such as RalGDS (Ral GDP dissociation stimulator), phosphatidylinositol3-kinase (PI3-K) or members of the Rho family, could be involved in the TSH actions. These observations, together with the new characterization of a family of cAMP-binding proteins that directly activate Rap1, open a new field of study on the role of these proteins in the thyroid. In this way, recent results suggest the need to reformulate concepts about cAMP-mediated signalling. Finally, we go over the effect of TSH on the cell cycle machinery. Thus, TSH induces cell cyclerelated gene expression such as G1 cyclins (D1, D3 and cyclin E) and CDK2, as well as down-regulates the universal CDK inhibitor p $27^{\text {Kip } 1}$. The resulting increases are reflected by an elevation in the hyperphosphorylated form of $\mathrm{Rb}$.

\section{Rat thyroid cell systems}

There is a broad range of in vitro models for studying thyroid growth and function. We can distinguish between primary cell cultures and established cell lines. Both have been widely used and have some advantages and handicaps, basically in the comparison of in vitro and in vivo situations, although the accumulated data proceeding from both experimental approaches should help to obtain a clearer view of thyroid physiology. The most frequently used rat cell line is FRTL-5 (23), which was obtained from a primary culture from 5- to 6-week-old rats of the NIH Fischer 344 inbred strain. Rat thyroid glands were excised, cut into small pieces and digested using standard methods for the isolation of primary cell lines $(27,28)$. Cells were cultured in a modified Ham's F-12 medium (29) supplemented with $0.1-0.5 \%$ donor calf serum and a hormone mixture, derived from the initial cocktail from Hayashi \& Sato (30) including $10 \mathrm{ng} / \mathrm{ml}$ glycyl-Lhistidyl-L-lysine, $5 \mu \mathrm{g} / \mathrm{ml}$ transferrin, $10 \mathrm{~nm}$ hydrocortisone, $10 \mathrm{ng} / \mathrm{ml}$ somatostatin, $10 \mu \mathrm{g} / \mathrm{ml}$ insulin, and 1 nм TSH. Primary culture was done in a low serum medium to avoid the selection of fibroblast-like cells, which are better adapted to growth in conventional culture conditions. The primary thyroid culture was completely dependent on TSH and insulin for growth and survival. Thus, the persistence of morphological and differentiated characteristics of the cells was dependent on TSH dose starting with $0.5 \mathrm{mU} / \mathrm{ml}$, and maximal growth stimulation was obtained between 5.0 and $10.0 \mathrm{mU} / \mathrm{ml}$.

The original FRTL strain grows with a doubling time of 5-7 days in the above-defined medium. The cells remain diploid with 42 chromosomes and the morphological characteristics of the primary FRTL culture remains unchanged. The individual cells are small with a small nucleus containing one or two nucleoli. The cells tend to grow in groups, forming follicle-like structures that grow on top after several weeks in culture, rather than expanding in a monolayer to fill the empty spaces on the dish. These cells maintain highly differentiated features typical of the thyroid phenotype such as Tg and TPO synthesis, iodine uptake and hormone dependence. Low serum conditions were critical during early passages, when the more differentiated cells are selected. Once isolated, a sub-strain of FRTL cells was grown in Ham's F-12, Coon's modified medium plus the six hormone mixture and 5\% serum (complete medium). These cells were called FRTL-5 cells, had a doubling time of $30-40 \mathrm{~h}$ and remained diploid and differentiated $(23,31-34)$. The continuous presence of TSH is a necessary requirement for cellular growth. Thus, removing TSH from the culture medium arrests cellular replication and this arrest is reversed by the readdition of TSH. Cell growth then resumes with a 2 day 'lag phase' in the continued presence of TSH (32). Insulin alone is not a growth factor for FRTL-5 cells, but its removal from the complete medium significantly reduces the growth rate (23). Insulin appears to be a permissive factor in TSH stimulation of FRTL-5 cell growth (35). None of the other factors present in the complete medium is a mitogen by itself, or can positively influence TSH-dependent cellular growth.

Other rat thyroid cell lines isolated by similar methods are the WRT (Wistar rat thyroid) (24) and the PC C13 cell lines (25) (Table 1). The main difference among these systems is the selection by cellular cloning from fibroblasts in the case of WRT and PC C13, versus selection by a low concentration of calf serum in the case of the FRTL cells. In addition, PC C13 cells were obtained from 18-month-old rats whereas WRT cells were obtained from 3- to 4-week-old rats. Furthermore, insulin itself acts as a mitogen in WRT cells whereas in the FRTL- 5 and PC C13 cells it is a permissive factor $(35,36)$. All are immortal cell lines from primary rat thyroid cultures which are considered 'normal': the cells are euploid, they do not grow in soft agar, do not show contact inhibition, and are not tumorigenic in euthyroid nude mice, although they can become tumorigenic when circulating TSH levels are artificially elevated after chemical destruction of the thyroid gland with $\mathrm{Na}^{131} \mathrm{I}$ (37) or after goitrogenic drug administration (38). The characteristics of the most useful rat thyroid cell lines appear in Table 1. 


\section{Extracellular signals involved in the control of thyroid cell proliferation}

TSH, insulin and IGF-I The main regulators of thyroid growth and function (39) are TSH and insulin, which recognize both insulin- and IGF-I receptors. Both can produce a dose-dependent increase in DNA synthesis and cell proliferation. When added together, insulin and TSH cooperate synergistically inducing a level of proliferation that is much greater than the sum of the effects of each one alone $(23,24,36)$. In PC C13 and FRTL-5 cells, insulin and TSH activate both growth in size and DNA replication (36). In FRTL-5, TSH alone promotes proliferation but this effect can be masked by the presence of the cytostatic agent somatostatin in the culture medium (40). Submitogenic concentrations of insulin $(50 \mathrm{ng} / \mathrm{ml})$ greatly potentiate the TSH effects in FRTL-5, PC C13, and WRT cells suggesting, once more, that insulin acts as a permissive factor for TSH action. Thus, it is possible to distinguish two major pathways stimulated at the level of the TSH-R or at the level of the insulin or IGF-I receptor.

TSH recognizes specific receptors on the thyrocyte surface and triggers the activation of adenylyl cyclase and other effectors via the heterotrimeric guanine nucleotide-binding protein (G-protein) (41). TSH-R belongs to a broad class of G-protein-coupled receptors. The basic structure of these receptors shows three domains: an extracellular segment at the N-terminus where the hormone binds, seven transmembrane helices, and three intracellular loops at the C-terminus (42, 43). Several experimental approaches demonstrated that the TSH-mediated response involves the activation of adenylyl cyclase and the increase of intracellular cAMP levels $(39,44)$. cAMP is the main second messenger in thyroid cells; thus agents which increase cAMP intracellular levels, such as forskolin or 8-bromo-cAMP, stimulate the expression of thyroidspecific genes, iodine uptake, the synthesis and secretion of thyroid hormones, and the growth of thyroid cells (34, 45, 46). In FRTL-5 cells, this second messenger stimulates both DNA synthesis and cell proliferation, and increases the levels of proto-oncogene mRNAs such as c-myc and c-fos $(47,48)$. In WRT cells, the microinjection of an antibody for the stimulatory G-protein of adenylate cyclase $\mathrm{G}_{\mathrm{s}}$ inhibits TSH-induced DNA synthesis (49). The importance of the TSH-R and cAMPdependent pathway in the control of thyroid cell proliferation is also demonstrated by the observation that TSH-R gene mutations, which constitutively activate this receptor, have been associated with the development of thyroid tumors. Thus, mutations in the TSH-R gene have been observed in human adenomas and in congenital hyperthyroidism (50-56). These mutations in the TSH-R gene permanently activate adenylyl cyclase leading to TSH-independent proliferation and to constitutive cAMP accumulation, as well as phosphatidylinositide pathway activation in some cases 
(57). Furthermore, the overexpression of TSH-R mutant proteins in FRTL-5 cells induce neoplastic transformation (58). Together, all these findings clearly suggest that the effects of TSH through its receptor are mainly due to increased intracellular cAMP levels.

The facts that insulin effects on thyroid cell growth are observed at pharmacological doses and mimicked by physiological doses of IGF-I suggest that insulin could act through the IGF-I receptors $(59,60)$. These receptors are glycoproteins that include two extracellular $\alpha$-subunits which bind the ligand and two $\beta$-subunits with an intrinsic tyrosine kinase activity on their intracellular domain (61). After insulin stimulation tyrosine kinase activity promotes the autophosphorylation of the receptor and other proteins such as insulin receptor substrates (IRS), Vav proto-oncogen, and adapter molecules such as Shc (62). These events activate signal transduction pathways, such as Ras/MAPK, PI3-K, and PKC (63$65)$, that finally regulate insulin target genes. There are several indications of a role for PKC in insulin action in FRTL-5 and PC $\mathrm{C} 13$ cells. Both insulin and TSH induce the synthesis of 1,2-diacylglycerol, the endogenous activator of PKC (66), while PKC activators such as the phorbol ester 12-O-tetradecanoyl-phorbol-13-acetate (TPA) mimic the effects of insulin in both cell lines. In fact TPA in PC C13 cells seems to be almost as potent as insulin $(36,67)$. In addition, co-stimulation with insulin and TPA in FRTL-5 or PC C13 cells does not synergize proliferation or protein synthesis, suggesting that both compounds activate the same pathway.

Together with insulin and IGF-I, there are several other growth factors that may also activate proliferation via mechanisms that are triggered by the activation of the tyrosine kinases $(68,69)$. Some of these factors have an autocrine effect on proliferation $(70,71)$. Thus, although it has been suggested that FRTL-5 cells lose the epidermal growth factor (EGF) response (39), recently Kimura et al. (36) reported a slight increase in $\left[{ }^{3} \mathrm{H}\right]$ thymidine-labeled nuclei after EGF or hepatocyte growth factor (HGF) stimulation in FRTL-5 cells, and this increase was potentiated by insulin. Conversely, PC C13 cells do not respond to EGF or HGF (36).

Other growth factors and local signals Epithelial cell proliferation is controlled by extracellular signals that include a variety of regulator peptides. Some of these factors are synthesized and released by the epithelial cells themselves and they act as an essential part of an autocrine mechanism. It is thought that the regulatory function of these factors mediates or modifies the local action of classic hormones. Thus, the TSH-mediated proliferation of thyrocytes might partially be due to the release and autocrine effects of these growth-promoting factors (72). The following are some of the growth factors associated with TSH-mediated proliferation.

ATP. The purinergic agonist ATP is a potent activator of the phosphatidylinositol 4,5-biphosphate/inositol-1,4,5- triphosphate $\left(\mathrm{PIP}_{2} / \mathrm{IP}_{3}\right)$ signal transduction pathway (73-76). In FRTL-5 cells, the activation of this pathway results in a substantial increase in intracellular free calcium levels. ATP acts as a potent co-mitogen in these cells, enhancing the incorporation of $\left[{ }^{3} \mathrm{H}\right]$ thymidine in the presence of insulin and TSH. This effect appears to be mediated by the activation of a MAPK pathway, although the mechanism of this activation remains unknown (77).

Sphingolipid metabolites. Sphingosine-1-phosphate (SPP) mobilizes sequestered calcium and stimulates proliferation in several different cell types. In FRTL-5 cells SPP rapidly mobilizes and sequesters calcium, which stimulates the entry of extracellular calcium and hereby increases the incorporation of $\left[{ }^{3} \mathrm{H}\right]$ thymidine in a dosedependent manner (78).

Amyloid peptides. The proteolytically released ectodomain of the $\beta$-amyloid precursor protein (APP) (72) is a single membrane-spanning glycoprotein known to serve as the macromolecular precursor for the amyloid peptide found in senile plaques and neurofibrillar tangles in the cerebral cortex of patients affected with Alzheimer's disease (79). APP is almost ubiquitously expressed and shows a high degree of evolutionary conservation $(80,81)$. Popp et al. (72) have demonstrated that APP promotes the growth of FRTL-5 cells and that the TSH-mediated proliferation might be related in part to APP activity.

Iodine. This element has an autoregulatory effect on various aspects of thyroid function and metabolism. Iodine deficiency may render a normal TSH concentration goitrogenic (39). Iodine inhibits thyroid growth and this is one of its major autoregulatory effects on this gland. This inhibition appears to be mediated by iodine interference with TSH-induced cAMP production although other inhibitory mechanisms may be involved (82). In addition, high iodine concentrations arrest the cell cycle at the G1 and G2-M phases, thus inhibiting FRTL-5 cell proliferation (83).

Other negative autocrine factors TGF- $\beta$. Transforming growth factor $\beta$ (i.e. three closely related isoforms TGF- $\beta 1,-\beta 2$ and $-\beta 3$ ) is a multifunctional cytokine with diverse biological actions that influence a wide range of cellular, physiological, immunological and developmental processes $(84,85)$. TGF- $\beta$ is the most potent inhibitor of in vivo and in vitro growth for a wide variety of cell type. Expression of TGF- $\beta$ precursor mRNA has been detected in most cell types, suggesting that it may mediate a negative autocrine loop that limits normal cell proliferation. TGF- $\beta 1$ has been found to inhibit proliferation in all the normal thyroid cell systems and, in some of these systems (86), it also prevents thyroid specific differentiation. On the other hand, TGF- $\beta 1$ 
precursor mRNA and/or immunoreactivity have been found in various pathological thyroid tissues, including follicular adenomas and malignant thyroid tumors (87). One example of the role of TGF- $\beta 1$ in the control of proliferation appears in thyroid hyperplasia during the development of a goiter when thyroid follicular cells proliferate in response to a goitrogen (for review see 88). When the thyroid has reached a certain size, growth stops despite continuous administration of the goitrogen and this effect is accompanied by a wide-spread expression of TGF- $\beta 1$ in the entire follicular epithelium; in normal thyroid the effect is restricted to parafollicular $C$ cells (89). Withdrawal of the goitrogen results in a reduction in size of the thyroid gland that is partly mediated by cell death (39). This process correlates with high levels of TGF- $\beta 1$ expression, suggesting that it plays a role in thyroid apoptosis. As in the in vivo situation, FRTL- 5 growth is also inhibited by TGF- $\beta 1$ in several physiological conditions. Thus, TGF- $\beta 1$ induces apoptosis in quiescent cells and arrests growth in proliferating cells that are not stimulated by the presence of a stronger mitogenic stimulus such as TSH or TSH plus IGF-I (90-92). In all these situations TGF$\beta 1$ decreases p $27^{\text {Kip } 1}$ mRNA, cyclin D1, cyclin E-CDK2 activity and retinoblastoma phosphorylation. On the other hand, TGF- $\beta 1$ increases p15 and c-myc mRNA expression (92). These findings suggest a physiological role for TGF- $\beta 1$ in the control of thyroid growth through the modification of cell cycle regulatory proteins. In addition, Morris et al. (91) found that TSH stimulates the production of a TGF- $\beta$-like activity by FRTL- 5 cells. This observation provides a good in vitro cell system to study the mechanism of TGF- $\beta$ action in the control of thyroid proliferation.

Somatostatin. Somatostatin was initially identified as a potent growth hormone (GH) inhibitor in the hypothalamus. Soon after, it was identified in many tissues and cell lines exerting different biological actions, including inhibition of hormone secretion processes, control of neural cognitive and locomotor functions, and regulation of cell proliferation $(93,94)$. Somatostatin has also been found in the thyroid, more specifically in parafollicular $\mathrm{C}$ cells, leading to the speculation that this peptide could have local effects on thyroid hormone release, as well as a local action as a paracrine peptide (95). In FRTL-5 cells, somatostatin inhibits TSH- and IGF-I-mediated proliferation (96). More recently, the effect of somatostatin on cell proliferation has also been characterized in PC C13. In these cells, somatostatin inhibits insulin-dependent and insulin plus TSH-dependent cell growth, blocking the G1-S transition of the cell cycle (97). Somatostatin action is mediated by at least six different subtypes of receptors (called SSTR-1, -2A, -2B, -3, -4, and -5) (98). These receptors, belonging to the seven transmembrane domain superfamily, are coupled to different G-proteins that link SSTR to distinct cellular effector systems, such as adenylyl cyclase, protein tyrosine phosphatases, and the $\mathrm{K}^{+}$and $\mathrm{Ca}^{2+}$ channels. They are responsible for the broad spectrum of somatostatin actions. Overexpression of SSTR-2 in several cell lines inhibited growth and increased the expression of preprosomatostatin mRNA accompanied by somatostatin secretion (98). In addition, SSTR expression correlated with the constitutive activation of a tyrosine phosphatase (99). Furthermore, somatostatin increased SSTR mRNA in a pitutary cell line (100). More recently, we provided evidence that somatostatin is also expressed in FRTL-5 cells and its transcription is under the control of TSH. Experiments with conditioned medium from TSH-treated FRTL-5 cells demonstrate that this peptide has a cytostatic effect on cell growth that promotes cell cycle arrest at the G1 phase. Somatostatin action is mediated by the cyclindependent kinase inhibitor $\mathrm{p} 27^{\text {Kip } 1}$, which is downregulated by TSH to promote proliferative signals. These findings suggest that, within thyroid follicular cells, somatostatin expression is a local mechanism that regulates cell growth in an autocrine fashion (40).

\section{Signal transduction pathways}

So far, we have described the main growth factors and inhibitory signals that control the complex regulation of thyrocyte proliferation. These factors exert their functions by activating several signal transduction pathways. Perhaps, as we have stated before, the TSHcAMP-PKA pathway may be the most important signal in the control of thyroid growth and function but there are other pathways that have been implicated in this regulation, PKC, MAPK and, recently, the PI3-K pathway. In summary, control of thyroid growth and function involves PKA-dependent and -independent pathways.

\section{PKA}

The cAMP-dependent PKA is held to mediate cAMP action. There are at least two types of PKA enzymes, PKAI and PKAII, each has a different cellular location, species and tissue distribution, as well as cAMP affinities (101). PKAI is a soluble cytoplasmic enzyme (102), while PKAII, $\alpha$ and $\beta$, are often associated with the cytoskeleton and Golgi apparatus, centrosomes and the perinuclear area (103-105). The regulation and localization of the catalytic (C) subunit of PKA is typically mediated through interaction with an inhibitory regulatory $(\mathrm{R})$ subunit, which sequesters the $\mathrm{C}$ subunit in an inactive state under physiological conditions (106-109). The inactive holoenzyme is a heterotetramer composed of two $\mathrm{R}$ and two $\mathrm{C}$ subunits. Activation is achieved when cytoplasmic cAMP binds to the $\mathrm{R}$ subunit, which then liberates the $\mathrm{C}$ subunit (110, 111). The RI subunit has a higher affinity for cAMP than RII $\alpha$ and $\beta(112,113)$ and a quicker turnover (114). These observations suggest that PKAI and PKAII 
decode cAMP signals with different duration and targets.

Classically, PKA activation promotes the phosphorylation of specific substrates such as CREB (cAMP response element binding protein). CREB binds to specific DNA sequences, called CREs, present in the promoters of the genes that are required for the control of the growth and differentiated phenotype in thyroid follicular cells (26). Phosphorylation of CREB at Ser-133 (115) and activation of cAMP-responsive genes occur within 1530 min of hormonal induction, coinciding with the time required for PKA to reach the nuclear compartment from the cytoplasm (116). In the continuous presence of hormones, transcription of cAMP-responsive genes is attenuated by protein phosphatase 1 (PP-1)-mediated, and, in some cases, PP-2A-mediated, desphosphorylation of CREB at Ser-133. Indeed, PP-1 inhibitors such as okadaic acid and the inhibitor- 1 protein can reverse the attenuation phase, thereby maintaining high levels of phospho-CREB, and in consequence target gene transcription. After the attenuation phase, there is a refractory phase induced by progressive loss of PKA activity as a consequence of $\mathrm{C}$ subunit protein downregulation (117). Proliferation and differentiation are the most important effects of PKA activation. Thus, CREB protein stimulates the expression of genes involved in cell division such as c-fos and c-myc, two genes induced by TSH and insulin in rat thyroid cell lines (47, 48). Data from in vivo and in vitro thyroid models suggest the preferential role of PKAI subtype in the control of cell proliferation (118). Microinjection of heat-stable PKA inhibitor (PKI) in WRT cells partially inhibited the TSH/ cAMP-mediated DNA synthesis (119). Paradoxically, microinjection of the PKA catalytic subunit failed to stimulate proliferation (120), suggesting that there are other PKA-independent signals that can contribute to cAMP-stimulated cell cycle progression.

In parallel, PKA also has an important role in thyroid differentiation, thus several thyroid specific genes such as Tg, TPO, TSH-R, $\mathrm{Na}^{+} / \mathrm{I}^{-}$symporter (NIS) and thyroid-specific transcription factors such as TTF-1, TTF-2 and Pax-8 (121) are regulated by TSH/cAMP (122), via PKA, and may be regulated by CREB or members of the CREB family. Exclusion of the catalytic PKA from the nucleus, after Ras transformation or PKC activation, correlates with the loss of transcriptionally active forms of TTF-1 and CREB proteins (123). Conversely, overexpression of catalytic PKA or depletion of the PKC reverses inhibition of Tg promoter activity by Ras (124). These effects from PKA activity appear to be mediated by a Ras-dependent delocalization and ultimate loss of the PKAII $\beta$ isoenzyme (125), again suggesting different functions for each PKA isoenzyme.

\section{PKC}

The PKC gene family is divided into three subgroups based on sequence homology and cofactor requirements: conventional PKCs $(\alpha, \beta \mathrm{I}, \quad \beta \mathrm{II}$ and $\gamma)$ which are dependent on $\mathrm{Ca}^{2+}$ for activation; non-conventional $\operatorname{PKCs}(\delta, \epsilon, \eta$ and $\mathrm{o})$ which are not dependent on $\mathrm{Ca}^{2+}$ for activation, and atypical PKCs $(\zeta$ and $\lambda / \iota)$ which are not stimulated by 1,2-diacylglycerol (DAG) or phorbol esters and are $\mathrm{Ca}^{2+}$ independent (126). Classically, PKC stimulation is dependent on inositol lipid hydrolysis. Thus, stimulation of phospholipase $\mathrm{C}$ catalyzes the hydrolysis of 4,5-bisphosphate $\left(\mathrm{PIP}_{2}\right)$ and generates inositol 1,4,5-trisphosphate $\left(\mathrm{IP}_{3}\right)$ and 1,2-diacylglycerol (DAG) (127). The resulting $\mathrm{IP}_{3}$ facilitates an increase in intracellular $\mathrm{Ca}^{2+}$ (128), while DAG activates PKC (126). Several pieces of evidence suggest that TSH plus insulin/ IGF-I can activate PKC by elevating DAG in FRTL- 5 cells, but this increase is independent of phospholipase $\mathrm{C}$ (PLC) activation at normal TSH concentration $(1-10 \mathrm{mU} / \mathrm{ml})$ $(66,129)$. The observation that TSH and its agonists forskolin and dibutyryl-cAMP (dbcAMP) can activate another phospholipase, PLD (responsible for the production of DAG from phosphatidylcholine hydrolysis), suggests an alternative mechanism for TSH-dependent activation of PKC (130). The PLD activation depends on PKA and $\mathrm{PKC}$ as has been demonstrated in experiments with specific inhibitors of both kinases (131).

There is marked heterogeneity in PKC isoforms among the thyroids of various species (132). When FRTL-5 cells are chronically exposed to TSH, the $\alpha, \delta, \epsilon$ and $\zeta$ PKC isoforms are expressed and all, except the last isoform, are activated by phorbol esters (133). When TSH-depleted FRTL-5 cells are stimulated with this hormone there is no effect on the cytosolic fractions of any of the PKC isoforms identified, but the membranebound fractions of $\alpha, \epsilon$ and $\zeta$ PKC after short-term exposure, and of $\delta \mathrm{PKC}$ after long-term exposure do increase (134). PKC isozymes are involved in signal transduction pathways controlling growth, differentiation and apoptosis $(135,136)$. In thyroid cells, PKC has been implicated in differentiation, inhibiting TSHmediated increase in iodine uptake and organification, cAMP production $(137,138)$ and $\mathrm{Tg}(139)$, and $5^{\prime} \mathrm{D}-\mathrm{I}$ expression (139). Moreover, the expression of PKC mimics the effects of Ras transformation, indicating a possible role as an effector downstream from Ras (122, 140, 141). In FRTL-5 cells, activation of PKC by phorbol esters have a mitogenic effect $(67,137)$. This effect is cAMP independent and also inhibits TSH-mediated cell growth, interfering with cAMP production (67). Although phorbol esters are pharmacological agents, their activation and effects may have a physiological relevance in view of evidence that other physiological agents, such as TSH, IGF-I or norepinephrine, may also activate PKC in the thyroid cell, $(66,129,142,143)$.

\section{PI3-kinase}

Phosphoinositide-3-kinases (PI3-Ks) are a subfamily of lipid kinases that catalyze the addition of a phosphate molecule specifically to the third position of the inositol 
ring of phosphoinositide. To date, nine members of the PI3-K family have been isolated in mammalian cells and they are grouped into three classes according to the molecules that they preferentially use as substrates $(144,145)$. PI3-K was first described as a PI-K activity associated with the viral oncoproteins, v-Src, v-Ros, and middle $\mathrm{T}$ polyomavirus. Mutational studies of these oncoproteins indicated a critical role for their associated PI3-K in cell transformation (146).

Usually, mitogenic signals that exert their action through tyrosine kinase receptors stimulate PI3-K $\alpha / \beta$ while those that activate G-protein-coupled receptors stimulate PI3-K $\gamma(147-150)$. PI3-K is required for the mitogenic activity of many growth factors such as PDGF, EGF and insulin. Most of these factors, specifically those requiring PI3-K activity, stimulate lipid kinase activity. The inactivation of this pathway by pharmacological inhibitors or microinjection of PI3-K-specific inhibitory antibodies or proteins (151-153) impairs growth factor-stimulated mitogenesis. Although cAMP has only been reported to inhibit PI3-K activity, these studies were performed in cells where cAMP failed to stimulate proliferation $(154,155)$. The biological effects of PI3-K are mediated through downstream kinases such as PDK1 (156-158), Akt (159-161), and p70s6k $(162,163)$. The small GTPase Rac1 is also activated downstream from PI3-K, where it contributes to p70s6k activation and stimulates membrane ruffling (164166). Recent reports using the WRT $(167,168)$ and FRTL-5 (169) cell systems suggest the possible implication of PI3-K in the TSH/cAMP-dependent growth of thyroid cells. Thus, TSH/cAMP stimulate membrane ruffling, Akt and p70s6k activity. Both the stimulation of membrane ruffling and Akt activity are PI3-K dependent, whereas the stimulation of p70s6k activity is PI3-K independent (although the possibility of some p70s6k activation by PI3-K cannot be discarded). In addition, treatment with the specific PI3-K inhibitor wortmannin or the expression of a dominant negative form of PI3-K causes a G1 arrest of FRTL-5 cells stimulated to proliferate with TSH (169). Moreover, $\mathrm{TSH} / \mathrm{cAMP}$ increases $\mathrm{p} 70 \mathrm{~s} 6 \mathrm{k}$ protein levels in a manner that appears to be cAMP dependent but PI3-K independent (167 and our unpublished observations). In all these cases, PI3-K activation by TSH is exclusively cAMP dependent and insulin independent because all these observations were performed in cells that had been arrested by the absence of insulin and TSH and that had been restimulated with TSH alone $(168,169)$.

\section{Ras signaling and thyroid cells}

General considerations Ras proteins are a group of $20-25 \mathrm{kDa}$ guanine nucleotide-binding proteins that function as molecular switches in many cellular signaling pathways. Thus, GTP-binding protein cycles between the GDP-bound inactive state and the
GTP-bound active state. Activation is dependent on external signaling and occurs when a guaninenucleotide exchange factor, GEF, accelerates nucleotide release from the protein. Once activated, Ras proteins can interact with the effector molecules generating a signal pathway that involves a broad range of effectors. Return to the inactive state is due to the GTP-binding protein capacity to hydrolyze GTP to GDP, a GTPase reaction that is accelerated by GTPase-activating proteins (GAPs) which are either regulatory proteins or can themselves be effectors (170-172).

In mammals, this superfamily of proteins is comprised of over 60 members, which, based on sequence and functional homology, can be divided into several subfamilies: Ras, Rho, Rab, Arf, Ran and Rad/Gem. The genes coding for these proteins are not only the most frequently activated oncogenes in cancer, but their corresponding proto-oncogenes are expressed in most mammalian tissues. They codify proteins that interact with a wide spectrum of regulators and downstream effectors producing different normal cellular responses such as proliferation, differentiation or apoptosis (173, 174). The expression of transforming Ras oncogenes interacts with the establishment and the maintenance of cellular differentiation in different tissues (175-178), including the thyroid. In this particular tissue, Ras inhibits the expression of thyroid-specific genes, and confers a proliferative advantage over normal thyroid cells $(123-125,140,141)$.

Inhibition of thyroid differentiation by Ras The growth of FRTL-5 cells transformed with a variety of activated oncogenes such as v-ras, v-src, v-raf and v-mos become TSH/cAMP independent. Furthermore, the thyroid differentiation markers are suppressed and so the transformed cells do not express Tg or TPO, do not respond to TSH and do not take up iodine (25). In parallel, the transcription factors controlling their expression are either not present or are inactive (140, $179,180)$. In K-Ras transformed cells, both Pax- 8 and TTF-1 mRNA are undetectable whereas in H-Ras, TTF-1 is present at normal levels and maintains its binding capacity although the cells lack the ability to express $\mathrm{Tg}$ and TPO (141). The mechanism inhibiting differentiation after Ras activation appears to down-regulate the catalytic PKA activity $(123,125)$. Inactivation of PKA decreases the phosphorylation of transcription factors such as TTF-1 and CREB, and inhibits the transcription of specific genes such as Tg, TPO or TSH-R that contain specific sites for these transcription factors $(121,124)$. The accumulated results suggest that by activating PKC, Ras finally inhibits the cAMP/PKA pathway The overexpression of PKC mimics the effects on thyroid cell differentiation exerted by the Ras transformation (124, 140, 141).

Ras effectors and mitogenesis Rat thyroid cell proliferation is dependent on both PKA as well as Ras 
activation. Overexpression of a constitutive inactive Ras form (Ras N17) significantly reduces TSH-mediated proliferation (120 and our unpublished observations). Concomitant overexpression of Ras N17 and a constitutive inactive PKA, fully suppress TSH-mediated proliferation, suggesting that both PKA and Ras are required for the full mitogenic action of TSH. Moreover, these results suggest that Ras function may be crucial in many G-protein-coupled signaling pathways in addition to its established role in tyrosine kinase-mediated pathways (120). Since TSH mitogenesis requires both signals, these must interact in some way. In several cell types in which intracellular cAMP levels inhibit growth, this second messenger exerts a negative effect on Rasmediated signaling pathways. Several findings suggest that PKA inhibits the proper binding of Ras protein to Raf, blocking the activation of the mitogen-activated protein (MAP)/extracellular signal-regulated kinase (ERK) kinase (MEK) and MAP kinases. In WRT cells, an increase in cAMP levels inhibits coupling of Ras to the Raf-dependent cytoplasmic kinase cascade (181183). In primary dog thyrocytes, MAP kinase phosphorylation is not implicated in TSH-mediated proliferation (184). In FRTL-5 thyroid cells, the specific inhibition of MEK by the inhibitor PD85059 does not affect TSH-mediated proliferation (169). All these findings suggest that the TSH pathway is Ras dependent but Raf- 1 and MEK independent and indicate that Ras signaling in TSH-treated cells might occur through an effector other than Raf. Some clues come from studies with mutant Ras effectors which differ in their ability to bind Raf (185). Thus, WRT cells overexpressing Ras (12V) or Ras (35S), which lead Ras to bind Raf, grow slowly in the presence of TSH, whereas another stable transfectant overexpressing Ras (37G) which only binds RalGDS, grows faster in the presence of TSH. These results suggest a role for a nucleotide exchange factor for Ral (RalGDS) in TSH-mediated proliferation. Several groups have shown that RalGDS is a Ras effector (186, 187). Dominant negative Ral mutants can suppress the oncogenic transformation induced by Ras in 50-75\% (188). This indicates that Ral activation by Ras-RalGDS mediates some of the downstream effects of Ras, although the functions of Ral have long remained elusive (189). In WRT cells, microinjection of the dominant negative RalA (RalA N28) reduces TSHand Ras-stimulated DNA synthesis (190). In addition, RalGDS can bind Rap1, a small Ras-like GTPase, identified as a protein that could suppress the oncogenic transformation of cells by Ras (188). Rap1 is activated by several extracellular stimuli and is involved in proliferation and differentiation. cAMP activates Rap1 in many cell types (191), including thyroid cells (168, 192), and cAMP-responsive Swiss 3T3 cells, where Rap1 acts as a mitogen (193) and as an oncogen (191). As we discussed before, recent reports have shown that one component of cAMP action is the inhibition of MAP kinase activation (194-196). Interestingly, the effects of
cAMP are very similar to those obtained after stable expression of a positive dominant form of Rap1 called Rap Val12. This mutant inhibits MAP kinase activation (197). This information tempts us to speculate that Rap1 plays a role in the cAMP-dependent inhibition of the MAP kinase pathway. The mechanism of this inhibition is unknown but one of the possible alternatives is that, upon activation, Rap may activate specific phosphatases that affect the Ras pathway at the Raf-1-MEK-MAP kinase activation step (191). Although the microinjection of wild-type Rap1 fails to induce proliferation or $\mathrm{Tg}$ expression in dog thyrocytes (192), this point remains to be studied in more detail using mutant forms of Rap1. All these recent findings open interesting questions about the effects of Rap1 overexpression on thyroid-specific markers under normal or Ras-transformed situations.

Recently, two different groups have reported (198, 199) that activation of Rap1 by forskolin and cAMP occurs independently of PKA. They cloned a gene encoding a guanine-nucleotide-exchange factor (GEF), called Epac (198), or cAMP-GEF (199), which contains a cAMP-binding site and a domain that is homologous to the GEF domain for Ras and Rap1. Thus, Epac seems to be a GEF for Rap1 that is regulated directly by cAMP. Epac is also expressed in the thyroid gland although its role is unclear and remains to be clarified. Thus, in this context, Epac may have an important function in the activation of proliferative or differentiative programs that are mediated by cAMP but are independent of PKA.

Rho family and thyroid The mammalian Rho family of GTPases, including RhoA, Rac1, and Cdc42, play pivotal roles in controlling many cellular functions, such as cell polarity, motility, proliferation, apoptosis, and cytokinesis (200). RhoA controls the assembly of actin stress fiber and focal adhesion complexes, Rac regulates actin filament accumulation at the plasma membrane to produce lamellipodia and membrane ruffles, and Cdc42 stimulates the formation of filopodia $(201,202)$. All these proteins also stimulate progression through phases G1 to $S$ of the cell cycle and their inhibitor forms can block serum-induced DNA synthesis (203). Rac1 and Cdc42 stimulate the JNK-SAPK cascade and lead to c-Jun transcriptional activity (204). RhoA is also involved in serum response factor (SRF) activation and acts synergistically with Rac1 and Cdc42 through a JNK-independent pathway (205).

All three proteins, Rho, Rac and Cdc42, cooperate with Raf in cell transformation and the dominant negative forms of RhoA, RhoB and Racl can inhibit Ras-induced transformation, indicating an essential role for these proteins in this process (206-210). Moreover, Rac1 and RhoA have also been implicated in the morphogenic and mitogenic responses to transformation by oncogenic Ras $(165,211)$. In the thyroid context, Cass et al. (168) described that activation of 
Rac1 by a PKA-independent pathway, via PI3 kinase after TSH/cAMP stimulation, promotes the formation of ruffles on WRT thyroid cells.

In several cell types, such as neural cells and lymphocytes, RhoA can be specifically phosphorylated at Ser-188 by PKA. This effect decreases the binding of RhoA to the downstream effector $\mathrm{ROK} \alpha$, suggesting that RhoA and cAMP have antagonistic roles in regulating cellular processes in these cells $(212,213)$. However, the role of cAMP is completely different in the thyroidal context. This second messenger activates a proliferative response in most of the thyroid cells systems studied. Noguchi et al. (214) suggest that RhoA activation after growth stimulation plays an essential role in the degradation of $\mathrm{p} 27^{\text {Kip } 1}$ with the resulting progression from phase G1 to $S$ in FRTL-5 cells. RhoA is geranylgeranylated and translocated to the membrane during this progression. Moreover, its activation is dependent on 3-hydroxy-3-methylglutaryl coenzyme A reductase (HMG-CoA-Red), the rate-limiting enzyme for the synthesis of isoprenoids such as the geranylgeranyl metabolites (215). This enzyme is transcriptionally regulated by TSH in FRTL-5 cells (216, 217). Results from our laboratory confirm the important role of RhoA in the control of TSH-mediated proliferation. Thus, overexpression of either the dominant negative form RhoA N19 or the specific inhibitor of RhoA activity, exoenzyme C3 (TC3), inhibits the FRTL-5 cells proliferation causing a G1 arrest. Moreover, the TSH-mediated activation of RhoA protein is PKA/HMG-CoA-Red dependent (169). The upstream regulators of RhoA are unknown but some authors, studying other cell systems, have proposed that Ras could activate RhoA-like proteins through its downstream effector RalGDS (218). Figure 1 presents a summary of our view on signaling in thyroid cells after the integration of the most recent observations.

\section{G1 phase progression in thyroid cells}

Key regulators of G1 progression in mammalian cells include three D-type cyclins (D1, D2 and D3), which

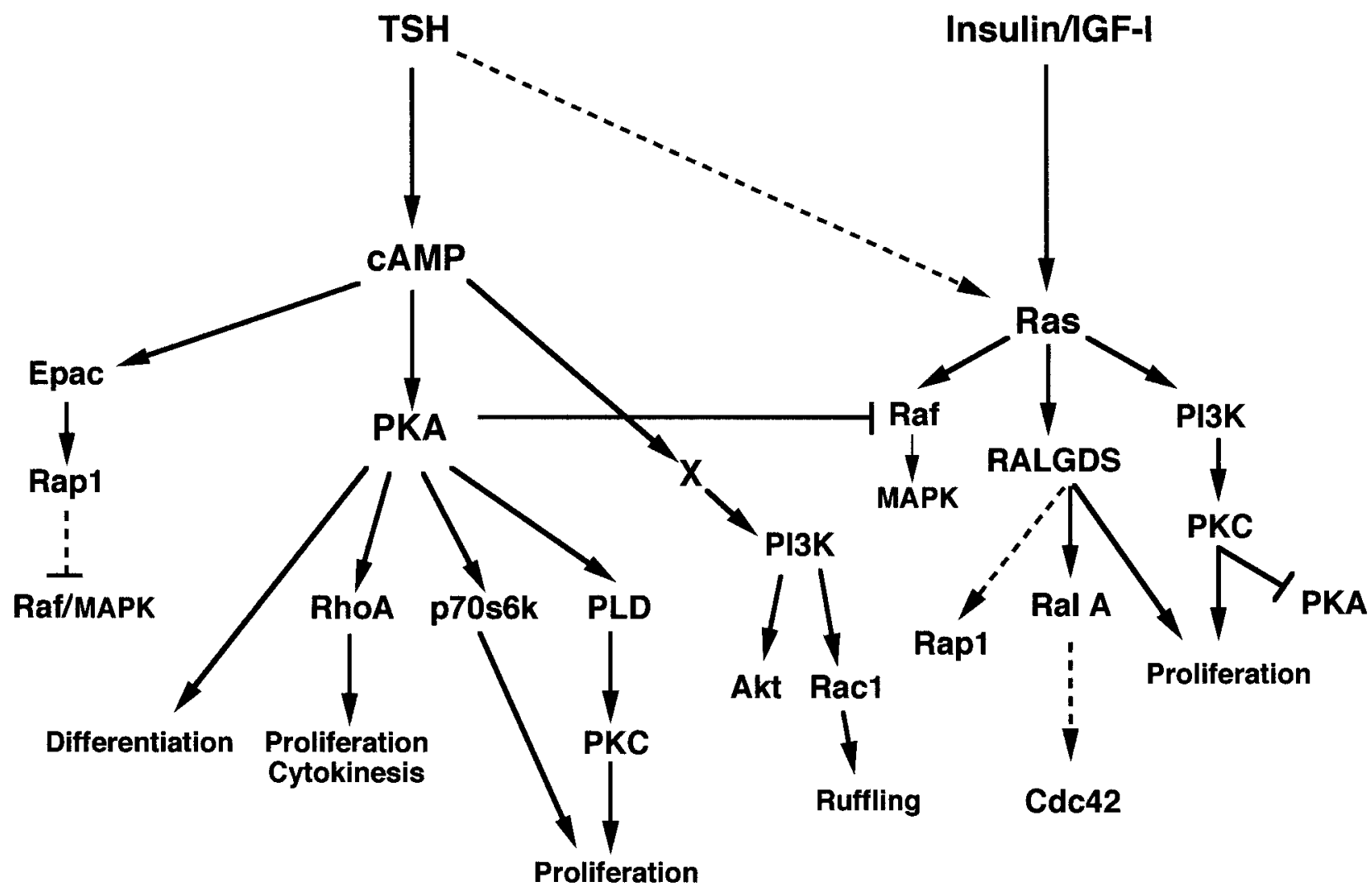

Figure 1 Hypothetical model of the signal transduction pathways induced by TSH and Insulin/IGF-I. TSH increases cAMP intracellular levels and eventually could activate Ras pathways. cAMP exerts its action through PKA-dependent and -independent pathways such as the CAMP-GEF (Epac) and PI3-K. All these pathways activate different downstream effectors that might interact with others pathways. In parallel, insulin activates Ras pathways and its downstream effectors (Raf, RalGDS and PI3-K). Finally all these pathways regulate several biological processes such as proliferation, differentiation and cytoskeletal remodeling. Symbols: arrows, activation; blocked bars, inhibition; dashed arrows, eventual pathways. 


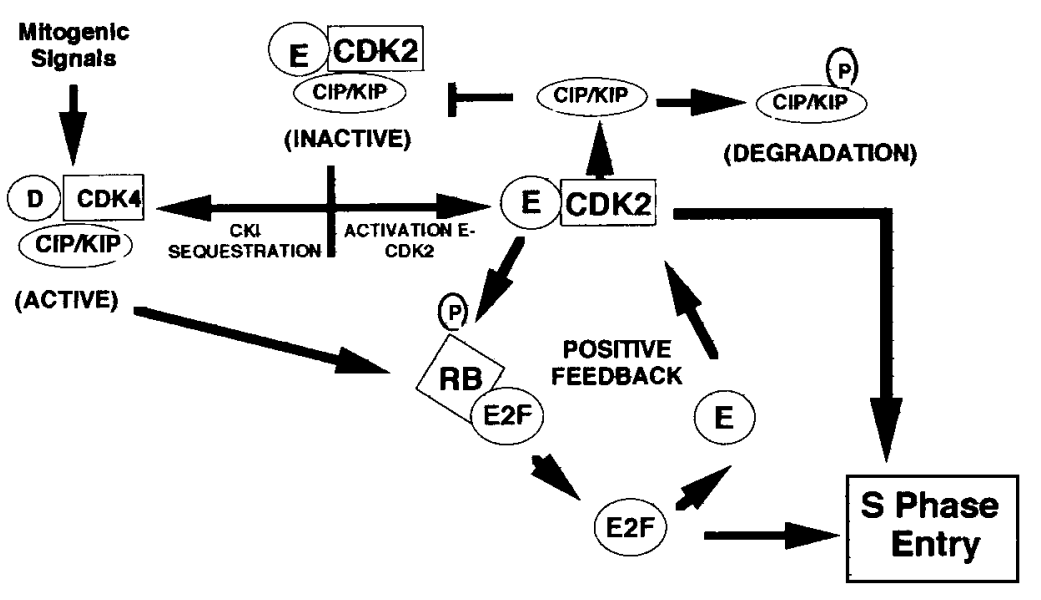

Figure 2 Regulation of the G1-S transition. Mitogenic signals promote the assembly of active cyclin D-dependent kinases containing either CDK4 or a Cip/Kip protein. Sequestration of Cip/ Kip proteins lowers the inhibitory threshold and facilitates activation of the cyclin E-CDK2 complexes. Both cyclin $D$ and $E$ contribute sequentially to $\mathrm{Rb}$ phosphorylation, canceling its ability to repress E2F family members and activating genes required for entry into $S$ phase. The latter includes cyclins $E$ and $A$, as well as a set of important genes that regulate DNA synthesis (for review see Nevins 1992, 236). Moreover, cyclin E-CDK2 complexes can phosphorylate p27Kip1 triggering its proteolysis. The degradation of Cip/ Kip proteins and the induction of cyclins by E2F (positive feedback) contribute to mitogen independence and to the irreversibility of the transition (modified from Sherr \& Roberts 1999, 6). Symbols: arrows, activation; blocked bars, inhibition.

assemble into holoenzymes with either CDK4 or CDK6, and cyclin E, which combines with CDK2 and is expressed weakly at the G1-S boundary (219). The timing and periodicity of cyclin E expression in mammalian cells suggest that this cyclin may control the ability of the cells to enter into the $S$ phase. Overexpression of D- or E-type cyclins can reduce the G1 phase, decrease cell size, and reduce the dependency of the cell on mitogens (220-222). Induction of D-type cyclin synthesis is strongly dependent on growth factors and D-cyclin levels decline precipitously when growth factors are withdrawn (223-225). Mitogen-induced Ras signaling promotes transcription and assembly of the cyclin D1 with CDK4 via Raf/MAPK (226-229). The degradation of D-type cyclins depends on a separate Ras signaling pathway involving PI3-K and Akt (230). These data suggest that D-type cyclins act primarily as growth factor sensors.

The D-type cyclins $(231,232)$, target CDK4 to $\mathrm{Rb}$ (233) and, unlike most CDKs, cyclin D-CDK4/6 phosphorylates $\mathrm{Rb}$ preferentially to histone $\mathrm{H} 1$ (234, 235). $\mathrm{Rb}$ binds to E2F-DP1 heterodimers and negatively regulates the activities of these transcription factors, with important functions in the G1-S transition. Phosphorylation of $\mathrm{Rb}$ on canonical $\mathrm{CDK}$ sites during middle to late G1 phase reverses the growth-suppressive effects of $\mathrm{Rb}$ by releasing E2F from its inhibitory constraint, thereby enabling the liberated factor to activate the genes required for DNA replication (236). Meanwhile, cyclin E preferentially forms complexes with CDK2 that phosphorylate substrates such as (i) histone $\mathrm{H} 1$ (237, 238), (ii) $\mathrm{Rb}$ (on sites other than where it is phosphorylated by D-CDK4/6) (239-243), (iii) the CDK inhibitor p $27^{\text {Kip } 1}(244,245)$, and (iv) possibly other substrates that help trigger the firing of replication origins (246-251) during late G1 and early S phase (see Fig. 2). Once cells enter the $S$ phase, cyclin $\mathrm{E}$ is degraded and CDK2 forms complex with cyclin A. The cyclin E-CDK2 and cyclin D-CDK4/6 complexes undergo phosphorylation on a single threonine residue, a modification required for their activation. This activation involves a multisubunit enzyme designated CDKactivating kinase (CAK) composed of a catalytic subunit (CDK7) and a novel cyclin (cyclin H) (252).

In FRTL- 5 cells, TSH, IGF-I, or a combination of both, induce G1 cyclin (D1, D3, and E) expression and accelerate the G1 phase $(40,92,253)$. In quiescent FRTL- 5 cells, levels of cyclin D1 and E are barely detectable; however, $24 \mathrm{~h}$ after TSH stimulation, their expression increases several fold (254). Stimulating growth in quiescent FRTL-5 cells with TSH, IGF-I and $5 \%$ calf serum results in an increase of CDK 4 and CDK2 expression, and correlates with an increase in the phosphorylated form of $\mathrm{Rb}$, all of which lead to cell cycle progression $(92,254)$. Moreover, results from our laboratory (169) indicate that the stimulation of quiescent FRTL-5 cells with TSH alone also increases both the expression levels of G1 cyclins (D1 and E) and CDK2 as well as the phosphorylation status of $\mathrm{Rb}$. These results suggest that TSH increases the assembly and activity of cyclin D-CDK4 and cyclin E-CDK2 complexes. This is demonstrated by the increase of both CDK2 kinase activity (measured in vitro using histone $\mathrm{H} 1$ as a substrate) and Rb phosphorylation (measured as indirect index of cyclin D-CDK4 activity).

Another level of CDK regulation comes from the binding of CDK inhibitors (CKIs) to cyclin-CDK complexes that then either inhibit their kinase activities or prevent their activation by CAK (6). The CKIs comprise two classes of proteins, the Ink4 family, which specifically inhibits cyclin D-dependent kinases, and the Cip/ Kip family, which can interact with virtually any cyclinCDK complex. The Ink4 family includes $15-20 \mathrm{kDa}$ proteins composed of repeated, loosely conserved ankyrin motif (1). The expression of p1 $5^{\operatorname{Ink} 4 b}$ is induced almost 30-fold in human keratinocytes treated with TGF- $\beta$. This induction is correlated with an increase of p1 $5^{\text {Ink } 4 b}$ binding to CDK4/ 6 resulting in a loss of activity (2). These findings suggest that p $15^{\text {Ink } 4 b}$ has a role as dominant effector of TGF- $\beta$-mediated cell cycle arrest in 
these cells. Thus, it has been proposed that TGF- $\beta$ treatment induces the $\mathrm{p} 15^{\text {Ink } 4 b}$ expression that shifts $\mathrm{p} 27^{\text {Kip } 1}$ from cyclin D-CDK4/6 to cyclin E-CDK2 complexes (255). In FRTL-5 cells this mechanism has not been implicated among the known TGF- $\beta$ effects and seems to be more related with the loss of $\mathrm{p} 27^{\text {Kip } 1}$ free cyclin D-CDK4/6 complexes that leads to the shift of free p $27^{\text {Kip } 1}$ to cyclin E-CDK2 and its consequent inactivation (92).

The Cip/Kip family comprises p21, p27 and p57 gene products. These CKIs can interact with many different cyclin-CDK complexes, raising the possibility that they might act as a cyclin-CDK assembly factor. While cyclin-CDK complexes containing a single molecule of this family are catalytically active, those containing multiple molecules are not. Thus, changes in the stoichiometry of CKIs are sufficient to modulate the complex activation (256). Although several CKIs have been identified as potent inhibitors of cyclin-CDK complexes, p $27^{\text {Kip } 1}$ is the only CKI whose protein expression decreases when mitogen-induced cells enter the cell cycle (257-260). p2 $7^{\text {Kip1 }}$ levels are elevated in quiescent cells and decline during the GO-S phase interval $(260,261)$. If the synthesis of CDK4 is inhibited by TGF- $\beta$ treatment, the free $\mathrm{p} 27^{\text {Kip } 1}$ levels inhibit cyclin E-CDK2 kinase activity and induce G1 arrest. Hence titration of $\mathrm{p} 27^{\text {Kip1 }}$ by cyclin D-CDK4/6 may promote cyclin-CDK2 kinase activity and help to establish the order of activation $(13,232)$. The decrease of $\mathrm{p} 27^{\text {Kip } 1}$ expression occurs through protein degradation via the ubiquitin-proteasome pathway (262). The existence of inhibitory levels of $\mathrm{p} 27^{\text {Kip } 1}$ appears to be involved in the growth-inhibitory properties of TGF- $\beta$, rapamycin, and cAMP $(13,14,261)$. In contrast, overexpression of $\mathrm{p} 27^{\text {Kip } 1}$ antisense cDNA results in mitogen-independent G1 progression, demonstrating the importance of $\mathrm{p} 27^{\text {Kip } 1}$ for maintaining cell quiescence $(263,264)$. Although the mitogenic signals responsible for $\mathrm{p} 27^{\text {Kip } 1}$ degradation have not been defined clearly, in Chinese hamster embryo fibroblast cells (IIC9 cells) PDGF stimulation causes the rapid activation of Ras and subsequent downstream activation of ERK $(227,265)$. In addition, Ras also stimulates the downstream activation of the RhoA that regulates $\mathrm{p} 27^{\text {Kip } 1}$ degradation to ensure the proper activation state of cyclin D1-CDK4 complexes following mitogenic stimulation (265). Interestingly, in thyroid cells where the cAMP is mitogenic, TSH stimulation down-regulates $\mathrm{p} 27^{\text {Kip } 1}$ and this effect correlates with an increases in cell proliferation (40). TSH downregulation of $\mathrm{p} 27^{\text {Kip } 1}$ appears to be mediated by the activation of RhoA protein after growth stimulation in FRTL-5 (254). These data indicate the important differences of cAMP signaling and the existence of specific circuits in different cell types.

\section{Concluding remarks}

In this work we have given an overview of the complex regulation of thyroid growth based on data accumulated using rat thyroid cell systems as an experimental model. These useful cell lines let us probe deeply into the main signal transduction pathways and cell cyclerelated genes implicated in TSH-mediated proliferation of thyroid cells. The data basically describe two main pathways involved in TSH/cAMP-mediated proliferation in rat thyroid cells, one that is PKA dependent and another that is PKA independent. The first pathway could implicate the small GTPase RhoA whereas the second one could involve Racl and Akt activation through PI3-K. On the other hand, TSH/cAMP can activate the p70s6k phosphorylation necessary for rat thyroid cell growth. The role of Ras in this context must be clarified, since this protein is necessary for TSHmediated proliferation although no direct activation of Ras after TSH treatment has yet been demonstrated. Moreover, the hierarchy of activation of the small GTPases, their downstream effectors, and possible crosstalk between different pathways remain elusive. To complicate the puzzle, the new cAMP-GEFs, which are also expressed in thyroid tissue, might have a role in cAMP-mediated proliferation that bypasses PKA and directly targets cAMP signal to small GTPases such as Rap1. The activation of these pathways finally converges and activates target genes involved in thyroid differentiation and cell cycle-related genes required for the $\mathrm{G} 1-\mathrm{S}$ phase transition.

\section{Acknowledgements}

We thank Carol Warren for her linguistic assistance. We are grateful to Dirección General de Investigación Científica y Tecnológica (Grant PM97-0065), Comunidad Autónoma de Madrid (Grants 08.1/0025.1/97 and 1/99) and Fundación Salud 2000 (Spain) for supporting our work.

DLM has a Fellowship from the Ministerio de Educación y Cultura (Spain).

\section{References}

1 Serrano M, Hannon GJ \& Beach D. A new regulatory motif in cell cycle control causing specific inhibition of cyclin D/CDK4. Nature $1993366704-707$.

2 Hannon GJ \& Beach D. p15INK4b is a potential effector of TGFbinduced cell cycle arrest. Nature 1994371 257-261.

3 Guan KL, Jenkins CW, Li Y, Nichols MA, Wu X, O'Keefe CL et al. Growth suppression by p18, a p16INK4/MTS1- and p15INK4b/ MTS2-related CDK6 inhibitor, correlates with wild-type pRb function. Genes and Development 19948 2939-2952.

4 Hirai H, Roussel MF, Kato J, Ashmun RA \& Sherr CJ. Novel INK4 proteins, p19 and p18, are specific inhibitors of the cyclin D-dependent kinases CDK4 and CDK6. Molecular and Cellular Biology $1995152672-2681$.

5 Chan FKM, Zhang J, Chen L, Shapiro DN \& Winoto A. Identification of human/mouse p19, a novel CDK4/CDK6 inhibitor with homology to p16ink4. Molecular and Cellular Biology 1995 15 2682-2688.

6 Sherr CJ \& Roberts JM. CDK inhibitors: positive and negative regulators of G1-phase progression. Genes and Development 1999 $131501-1512$. 
$7 \mathrm{Gu}$ Y, Turek CW \& Morgan DO. Inhibition of CDK2 activity in vivo by an associated 20K regulatory subunit. Nature 1993366 707-710.

8 Harper JW, Adami GR, Wei N, Keyomarsi K \& Elledge SJ. The p21 cdk-interacting protein Cip1 is a potent inhibitor of G1 cyclindependent kinases. Cell 199375 805-816.

9 El-Deiry WS, Tokino T, Velculescu VE, Levy DB, Parsons R, Trent JM et al. WAF1, a potential mediator of p53 tumor suppression. Cell 199375 817-825.

10 Xiong Y, Hannon GJ, Zhang H, Casso D, Kobayashi R \& Beach D. p21 is a universal inhibitor of cyclin kinases. Nature 1993366 $701-704$.

11 Dulic V, Kaufmann WK, Wilson SJ, Tlsty TD, Lees E, Harper JW, Elledge SJ et al. p53-dependent inhibition of cyclin-dependent kinase activities in human fibroblasts during radiation-induced G1 arrest. Cell 199476 1013-1023.

12 Noda A, Ning Y, Venable SF, Pereira-Smith OM \& Smith JR. Cloning of senescent cell-derived inhibitors of DNA-synthesis using an expression screen. Experimental Cell Research 1994211 90-98.

13 Polyak K, Kato JY, Solomon MJ, Sherr CJ, Massagué J, Roberts JM et al. p27Kip1, a cyclin-cdk inhibitor links transforming growth factor- $\beta$ and contact inhibition to cell cycle arrest. Genes and Development 19948 9-22.

14 Toyoshima H \& Hunter T. p27, a novel inhibitor of G1 cyclin/cdk protein kinase activity, is related to p21. Cell 199478 67-74.

15 Lee MH, Reynisdóttir I \& Massagué J. Cloning of p57Kip2, a cyclin-dependent kinase inhibitor with unique domain structure and tissue distribution. Genes and Development 1995 9 639-649.

16 Matsuoka S, Eduards M, Bai C, Parker S, Zhang P, Baldini A et al. P57Kip2, a structurally distinct member of the p21CIP1 cdk inhibitor family, is a candidate tumor suppressor gene. Genes and Development 19959 650-662.

17 Chen J, Jackson PK, Kirschner MW \& Dutta A. Separate domains of p21 involved in the inhibition of cdk kinase and PCNA. Nature $1995374386-388$.

18 Chen J, Saha P, Kornbluth S, Dynlacht BD \& Dutta A. Cyclinbinding motifs are essential for the function of p21Cip1. Molecular and Cellular Biology 199616 4673-4682.

19 Nakanishi M, Robetorge RS, Adami GR, Pereira-Smith OM \& Smith JR. Identification of the active region of the DNA-synthesis inhibitory gene p21Sdi1/CIP1/WAF1. EMBO Journal 199514 555-563.

20 Warbrick E, Lane DP, Glover DM \& Cox LS. A small peptide inhibitor of DNA replication defines the site of interaction between the cyclin-dependent inhibitor p21WAF1 and proliferating cell nuclear antigen. Current Biology 19955 275-282.

21 Lin J, Reichner C, Wu X \& Levine AJ. Analysis of wild-type and mutant p21WAF1 gene activities. Molecular Biology of the Cell $1996161786-1793$.

22 Russo AA, Jeffrey PD, Patten AK, Massagué J \& Pavletich NP. Crystal structure of the p27Kip1 cyclin-dependent kinase inhibitor bound to the cyclin A-cdk2 complex. Nature 1996 382 325-331.

23 Ambesi-Impiombato FS, Parks LAM \& Coon HG. Culture of hormone-dependent functional cells of rat thyroid. PNAS 1980 77 3455-3459.

24 Brandi ML, Rotella CM, Mavilia C, Francescheli F, Tanini A \& Toccafondi R. Insulin stimulates cell growth of a new strain of differentiated rat thyroid cells. Molecular and Cellular Endocrinology $19875491-103$

25 Fusco A, Berlingieri MT, Portella G, Di Fiore PP, Grieco M \& Vecchio G. One- and two-step transformation of rat thyroid epithelial cells by retroviral oncogenes. Molecular and Cellular Biology 19877 3365-3370.

26 Woloshin PL, Walton KM, Rehfuss RP, Goodman RH \& Cone RD. $3^{\prime}, 5^{\prime}$-Cyclin adenosine monophosphate-regulated enhancer binding (CREB) activity is required for normal growth and differentiated phenotype in the FRTL-5 thyroid follicular cell line. Molecular Endocrinology 19926 1725-1733.
27 Tong W. The isolation and culture of thyroid cells. Methods in Enzymology 197432 745-758.

28 Winand RJ \& Kohn LD. Thyrotropin effects on thyroid cells in culture. Effects of trypsin on the thyrotropin receptor and on thyrotropin-mediated cyclic $3^{\prime}: 5^{\prime}$-AMP changes. Journal of Biological Chemistry $19752506534-6540$.

29 Coon HG. Clonal stability and phenotypic expression of chick cartilage cells in vitro. PNAS 196655 66-73.

30 Hayashi I \& Sato GH. Replacement of serum by hormones permits growth of cells in a defined medium. Nature 1976259 $132-134$.

31 Tramontano D, Avivi A, Ambesi-Impiombato FS, Barak L, Geiger B \& Schlessinger J. Thyrotropin induces changes in the morphology and the organization of microfilament structures in cultured thyroid cells. Experimental Cell Research 1982137 269-275.

32 Valente WA, Vitti P, Kohn LD, Brandi ML, Rotella CM, Toccafondi $\mathrm{R}$ et al. The relationship of growth and adenylate cyclase activity in cultured thyroid cells: separate bioeffects of thyrotropin. Endocrinology $198311271-79$.

33 Vitti P, Rotella CM, Valente WA, Cohen J, Aloj SM, Laccetti P et al. Characterization of the optimal stimulatory effects of Graves' monoclonal and serum immunoglobulin $\mathrm{G}$ on adenosine $3^{\prime}, 5^{\prime}$-monophosphate production in FRTL-5 thyroid cells: a potential clinical assay. Journal of Clinical Endocrinology and Metabolism $198357782-791$.

34 Weiss SJ, Philp NJ \& Grollman EF. Iodide transport in a continuous line of cultured cells from rat thyroid. Endocrinology 1984114 1090-1098.

35 Smith P, Wynford-Thomas D, Stringer BM \& Williams ED. Growth factor control of rat thyroid follicular cell proliferation. Endocrinology $19861191439-1445$.

36 Kimura T, Dumont JE, Fusco A \& Golstein J. Insulin and TSH promote growth in size of $\mathrm{PC} \mathrm{Cl} 3$ rat thyroid cells, possibly via a pathway different from DNA synthesis: comparison with FRTL-5 cells. European Journal of Endocrinology 1999140 94-103.

37 Ossendorp FA, Bruning PF, Schuuring EM, Van Den Brink JA, van der Heide D, De Vijlder JJ et al. Thyrotropin dependent and independent thyroid cell lines selected from FRTL-5 derived tumors grown in nude mice. Endocrinology 1990127 419-430.

38 Peter HJ, Gerber H, Studer H, Groscurth P \& Zakarija M. Comparison of FRTL-5 cell growth in vitro with that of xenotransplanted cells and the thyroid of the recipient mouse. Endocrinology 1991128 211- 219.

39 Dumont JE, Lamy F, Roger P \& Maenhaut C. Physiological and pathological regulation of thyroid cell proliferation and differentiation by thyrotropin and others growth factors. Physiological Reviews 199272 667-698.

40 Medina DL, Velasco JA \& Santisteban P. Somatostatin is expressed in FRTL-5 thyroid cells and prevents thyrotropinmediated down-regulation of the cyclin-dependent kinase inhibitor p27kip1. Endocrinology 1999140 87-95.

41 Porcellini A, Fenzi G \& Avvedimento EV. Mutations of thyrotropin receptor gene. Journal of Molecular Medicine 199775 $567-575$.

42 Cotecchia S, Exum S, Caron MG \& Lefkowitz RJ. Regions of the alpha 1-adrenergic receptor involved in coupling to phosphatidylinositol hydrolysis and enhanced sensitivity of biological function. PNAS 199087 2896-2900.

43 Lefkowitz RJ. G proteins. The subunit story thickens. Nature 1992358372

44 Jin S, Hornicek FJ, Neylan D, Zakarija M \& McKenzie JM. Evidence that adenosine $3^{\prime}, 5^{\prime}$-monophosphate mediates stimulation of thyroid growth in FRTL5 cells. Endocrinology 1986119 $802-810$.

45 Vassart G \& Dumont JE. The thyrotropin receptor and the regulation of thyrocyte function and growth. Endocrine Reviews $199213596-611$

46 Avvedimento VE, Tramontano D, Ursini MV, Monticelli A \& Di 
Lauro R. The level of thyroglobulin mRNA is regulated by TSH both in vitro and in vivo. Biochemical and Biophysical Research Communications $1984122472-477$.

47 Tramontano D, Chin WW, Moses AC \& Ingbar SH. Thyrotropin and dibutyryl cyclic AMP increase levels of c-myc and c-fos mRNAs in cultured rat thyroid cells. Journal of Biological Chemistry $19862613919-3922$.

48 Isozaki O \& Kohn LD. Control of c-fos and c-myc proto-oncogene induction in rat thyroid cells in culture. Molecular Endocrinology $19871839-848$

49 Meinkoth JL, Goldsmith PK, Spiegel AM, Feramisco JR \& Burrow GN. Inhibition of thyrotropin-induced DNA synthesis in thyroid follicular cells by microinjection of an antibody to the stimulatory G protein of adenylate cyclase, Gs. Journal of Biological Chemistry 1992267 13239-13245.

50 Russo D, Arturi F, Wicker R, Chazenbalk GD, Schlumberger M, DuVillard JA et al. Genetic alterations in thyroid hyperfunctioning adenomas. Journal of Clinical Endocrinology and Metabolism $1995801347-1351$

51 Paschke R, Metcalfe A, Alcalde L, Vassart G, Weetman A \& Ludgate M. Presence of nonfunctional thyrotropin receptor variant transcripts in retroocular and other tissues. Journal of Clinical Endocrinology and Metabolism 199479 1234-1238.

52 Parma J, Duprez L, Van Sande J, Cochaux P, Gervy C, Mockel J et al. Somatic mutations in the thyrotropin receptor gene cause hyperfunctioning thyroid adenomas. Nature 1993 365 649-651.

53 Duprez L, Parma J, Van Sande J, Allgeier A, Leclere J, Schvartz C et al. Germline mutations in the thyrotropin receptor gene cause non-autoimmune autosomal dominant hyperthyroidism. Nature Genetics 19947 396-401.

54 Kopp P, Kimura ET, Aeschimann S, Oestreicher M, Tobler A, Fey MF et al. Polyclonal and monoclonal thyroid nodules coexist within human multinodular goiters. Journal of Clinical Endocrinology and Metabolism 199479 134-139.

55 de Roux N, Polak M, Couet J, Leger J, Czernichow P, Milgrom B et al. A neomutation of the thyroid-stimulating hormone receptor in a severe neonatal hyperthyroidism. Journal of Clinical Endocrinology and Metabolism 199681 2023-2026.

56 Tonacchera M, Cetani F, Parma J, Van Sande J, Vassart G \& Dumont J. Oncogenic mutations in thyroid adenoma: methodological criteria. European Journal of Endocrinology 1996135 444-446.

57 Parma J, Van Sande J, Swillens S, Tonacchera M, Dumont J \& Vassart G. Somatic mutations causing constitutive activity of the thyrotropin receptor are the major cause of hyperfunctioning thyroid adenomas: identification of additional mutations activating both the cyclic adenosine $3^{\prime}, 5^{\prime}$-monophosphate and inositol phosphate-Ca ${ }^{2+}$ cascades. Molecular Endocrinology 1995 $9725-733$.

58 Fournes B, Monier R, Michiels F, Milgrom E, Misrahi M \& Feunteun J. Oncogenic potential of a mutant human thyrotropin receptor expressed in FRTL-5 cells. Oncogene 1998 16 985-990.

59 Santisteban P, Kohn LD \& Di Lauro R. 12. Thyroglobulin gene expression is regulated by insulin and insulin-like growth factor I (IGF-I) as well as thyrotropin in FRTL-5 thyroid cells. Journal of Biological Chemistry 1997262 4049-4052.

60 Tramontano D, Cushing GW, Moses AC \& Ingbar SH. Insulin-like growth factor-I stimulates growth of rat thyroid cells in culture and synergizes the stimulation of DNA synthesis induced by TSH and Graves-IgG. Endocrinology 1986119 940-942.

61 Ullrich A, Bell JR, Chen EY, Herrera R, Petruzzelli LM, Dull TJ et al. Human insulin receptor and its relationship to the tyrosine kinase family of oncogenes. Nature 1985313 756-761.

62 Myers MG \& White MF. Insulin signal transduction and the IRS proteins. Annual Review of Pharmacology and Toxicology 199636 $615-658$

63 Ouwens DM, Van der Zon GC, Pronk GJ, Bos JL, Moller W, Cheatham B et al. A mutant insulin receptor induces formation of a Shc-growth factor receptor bound protein 2 (Grb2) complex and p21ras-GTP without detectable interaction of insulin receptor substrate 1 (IRS1) with Grb2. Evidence for IRS1independent p21ras-GTP formation. Journal of Biological Chemistry $199426933116-33122$.

64 Skolnik EY, Lee CH, Batzer A, Vicentini LM, Zhou M, Daly R et al. The $\mathrm{SH} 2 / \mathrm{SH} 3$ domain-containing protein GRB2 interacts with tyrosine-phosphorylated IRS1 and Shc: implications for insulin control of ras signalling. EMBO Journal 199312 1929-1936.

65 Backer JM, Myers MG Jr, Shoelson SE, Chin DJ, Sun XJ, Miralpeix $\mathrm{M}$ et al. Phosphatidylinositol 3'-kinase is activated by association with IRS-1 during insulin stimulation. EMBO Journal 199211 3469-3479.

66 Brenner-Gati L, Trowbridge JM, Moucha CS \& Gershengorn MC. Thyrotropin-induced elevation of 1,2-diacylglycerol and stimulation of growth of FRTL- 5 cells are not dependent on inositol lipid hydrolysis. Endocrinology 1990126 1623-1629.

67 Lombardi A, Veneziani BM, Tramontano D \& Ingbar SH. Independent and interactive effects of tetradecanoyl phorbol acetate on growth and differentiated functions of FRTL5 cells. Endocrinology $19881231544-1552$.

68 Takada K, Amino N, Tada H \& Miyai K. Relationship between proliferation and cell cycle-dependent $\mathrm{Ca}^{2+}$ influx induced by a combination of thyrotropin and insulin-like growth factor-I in rat thyroid cells. Journal of Clinical Investigation $1990861548-$ 1555.

69 Isozaki O, Emoto N, Tsushima T, Sato Y, Shizume K, Demura H et al. Opposite regulation of deoxyribonucleic acid synthesis and iodide uptake in rat thyroid cells by basic fibroblast growth factor: correlation with opposite regulation of c-fos and thyrotropin receptor gene expression. Endocrinology 1992131 2723-2732.

70 Maciel RM, Moses AC, Villone G, Tramontano D \& Ingbar SH. Demonstration of the production and physiological role of insulin-like growth factor II in rat thyroid follicular cells in culture. Journal of Clinical Investigation 1988 82 1546-1553.

71 Logan A, Black EG, Gonzalez AM, Buscaglia M \& Sheppard MC. Basic fibroblast growth factor: an autocrine mitogen of rat thyroid follicular cells? Endocrinology 1992130 23632372.

72 Popp GM, Graebert KS, Pietrzik CU, Rosentreter SM, Lemansky P \& Herzog V. Growth regulation of rat thyrocytes (FRTL-5 cells) by the secreted ectodomain of beta-amyloid precursor-like proteins. Endocrinology 1996137 1975-1983.

73 Okajima F, Sho K \& Kondo Y. Inhibition by islet-activating protein, pertussis toxin, of $\mathrm{P} 2$-purinergic receptor-mediated iodide efflux and phosphoinositide turnover in FRTL-5 cells. Endocrinology 1988123 1035-1043.

74 Okajima F, Sato K \& Kondo Y. P2-purinergic agonists activate phospholipase $\mathrm{C}$ in a guanine nucleotide-and $\mathrm{Ca}^{2+}$-dependent manner in FRTL-5 thyroid cell membranes. FEBS Letters 1989 253 132-136.

75 Rani CS, Schilling WP \& Field JB. Intracellular $\mathrm{Ca}^{2+}$ mobilization by thyrotropin, carbachol, and adenosine triphosphate in dog thyroid cells. Endocrinology 1989125 1889-1897.

76 Raspe E, Laurent E, Andry G \& Dumont JE. ATP, bradykinin, TRH and TSH activate the $\mathrm{Ca}\left({ }^{2+}\right)$-phosphatidylinositol cascade of human thyrocytes in primary culture. Molecular and Cellular Endocrinology 199181 175-183.

77 Tornquist K, Ekokoski E \& Dugue B. Purinergic agonist ATP is a comitogen in thyroid FRTL-5 cells. Journal of Cell Physiology $1996166241-248$.

78 Tornquist K, Saarinen P, Vainio M \& Ahlstrom M. Sphingosine 1-phosphate mobilizes sequestered calcium, activates calcium entry, and stimulates deoxyribonucleic acid synthesis in thyroid FRTL-5 cells. Endocrinology 1997138 4049-4057.

79 Selkoe DJ. Cell biology of the amyloid $\beta$-protein precursor and the mechanism of Alzheimer's disease. Annual Review of Cell and Developmental Biology 199410 373-403.

80 Rosen DR, Martin-Morris L, Luo LO \& White K. A Drosophila gene encoding a protein resembling the human beta-amyloid protein precursor. PNAS $1989862478-2482$. 
81 Robakis NK, Ramakrishna N, Wolfe G \& Wisniewski HM Molecular cloning and characterization of a cDNA encoding the cerebrovascular and the neuritic plaque amyloid peptides. PNAS 198784 4190-4194.

82 Tramontano D, Veneziani BM, Lombardi A, Villone G \& Ingbar SH. Iodine inhibits the proliferation of rat thyroid cells in culture. Endocrinology $1989125984-992$.

83 Smerdely P, Pitsiavas V \& Boyages SC. Evidence that the inhibitory effects of iodide on thyroid cell proliferation are due to arrest of the cell cycle at G0-G1 and G2-M phases. Endocrinology 1993133 2881-2888.

84 Border WA \& Ruoslahti E. Transforming growth factor-beta in disease: the dark side of tissue repair. Journal of Clinical Investigation $1992901-7$.

85 Kulkarni AB \& Karlsson S. Transforming growth factor-beta 1 knockout mice. A mutation in one cytokine gene causes a dramatic inflammatory disease. American Journal of Pathology $19931433-9$

86 Taton M, Lamy F, Roger PP \& Dumont JE. General inhibition by transforming growth factor beta 1 of thyrotropin and cAMP responses in human thyroid cells in primary culture. Molecular and Cellular Endocrinology 199395 13-21.

87 Roger PP. Thyrotropin-dependent transforming growth factor beta expression in thyroid gland. European Journal of Endocrinology $1996134269-271$.

88 Bidey SP, Hill DJ \& Eggo MC. Growth factors and goitrogenesis. Journal of Endocrinology $1999160321-332$.

89 Logan A, Smith C, Becks GP, Gonzalez AM, Phillips ID \& Hill DJ. Enhanced expression of transforming growth factor-beta 1 during thyroid hyperplasia in rats. Endocrinology 1994141 45-57.

90 Pang XP, Park M \& Hershman JM. Transforming growth factorbeta blocks protein kinase-A-mediated iodide transport and protein kinase-C-mediated DNA synthesis in FRTL-5 rat thyroid cells. Endocrinology 1992131 45-50.

91 Morris IC 3d, Ranganathan G, Hay ID, Nelson RE \& Jiang NS. The effects of transforming growth factor-beta on growth and differentiation of the continuous rat thyroid follicular cell line, FRTL-5. Endocrinology 1988123 1385-1394.

92 Carneiro C, Alvarez CV, Zalvide J, Vidal A \& Dominguez F. TGFbeta 1 actions on FRTL- 5 cells provide a model for the physiological regulation of thyroid growth. Oncogene $1998161455-$ 1465 .

93 Brazeau P, Vale W, Burgus R, Ling N, Butcher M, Rivier J et al. Hypothalamic polypeptide that inhibits the secretion of immunoreactive pituitary growth hormone. Science 1973 179 77-79.

94 Reichlin S. Somatostatin. New England Journal of Medicine 1983 309 1495-1563.

95 Noorden SV, Polak JM \& Pearse AGE. Single cellular origin of somatostatin and calcitonin in the rat thyroid gland. Histochemistry 197753 243-247.

96 Tsuzaki S \& Moses AC. Somatostatin inhibits deoxyribonucleic acid synthesis induced by both thyrotropin and insulin-like growth factor-I in FRTL5 cells. Endocrinology 19901263131 3138.

97 Florio T, Scorizello A, Fattore M, D’Alto V, Salzano S, Rossi G et al. Somatostatin inhibits $\mathrm{PC} \mathrm{Cl3}$ thyroid cell proliferation through the modulation of phosphotyrosine activity. Impairment of the somatostatinergic effects by stable expression of E1A viral oncogene. Journal of Biological Chemistry 1996271 6129-6136.

98 Reisine T. Somatostatin receptors. American Journal of Physiology 1995269 G813-G820.

99 Rauly I, Saint-Laurent N, Delesque N, Buscail L, Esteve JP, Vaysse $\mathrm{N}$ et al. Induction of a negative autocrine loop by expression of sst2 somatostatin receptor in NIH $3 \mathrm{~T} 3$ cells. Clinical Investigations 199697 1874-1883.

100 Bruno JF, Xu Y \& Berelowitz M. Somatostatin regulates somatostatin receptor subtype mRNA expression in GH3 cells. Biochemical and Biophysical Research Communications 1994202 1738-1743.
101 Doskeland SO, Maronde E \& Gjertsen BT. The genetic subtypes of cAMP-dependent protein kinase - functionally different or redundant? Biochimica et Biophysica Acta 19931178 249-258.

102 Ndubuka C, Li Y \& Rubin CS. Expression of a kinase anchor protein 75 depletes type II cAMP-dependent protein kinases from the cytoplasm and sequesters the kinases in a particulate pool. Journal of Biological Chemistry 1993268 7621-7624.

103 Nigg EA, Hiltz HM, Eppenberger HM \& Dutly F. Rapid and reversible translocation of the catalytic subunit of cAMPdependent protein kinase type II from the Golgi complex to the nucleus. EMBO Journal 19854 2801-2806.

104 Rios RM, Celati C, Lohmann SM, Bornes M \& Keryer G. Identification of a high affinity binding protein for the regulatory subunit RII beta of cAMP-dependent protein kinase in Golgi enriched membranes of human lymphoblasts. EMBO Journal $1992111723-1731$.

105 Keryer G, Luo Z, Cavadore JC, Erlichman J \& Bornes M. Phosphorylation of the regulatory subunit of type II beta cAMP-dependent protein kinase by cyclin B/p34cdc2 kinase impairs its binding to microtubule-associated protein 2. PNAS $1993905418-5422$.

106 Bregman DB, Bhattacharyya N \& Rubin CS. High affinity binding protein for the regulatory subunit of cAMP-dependent protein kinase II-B. Cloning, characterization, and expression of cDNAs for rat brain P150. Journal of Biological Chemistry 1989264 4648-4656.

107 Glantz SB, Amat JA \& Rubin CS. cAMP signaling in neurons: patterns of neuronal expression and intracellular localization for a novel protein, AKAP 150, that anchors the regulatory subunit of cAMP-dependent protein kinase II beta. Molecular Biology of the Cell 19923 1215-1228.

108 Hirsch AH, Glantz SB, Li Y, You Y \& Rubin CS. Cloning and expression of an intron-less gene for AKAP 75, an anchor protein for the regulatory subunit of cAMP-dependent protein kinase II beta. Journal of Biological Chemistry $19922672131-$ 2134.

109 Scott JD \& McCartney S. Localization of A-kinase through anchoring proteins. Molecular Endocrinology 1994 8 5-11.

110 Taylor SS, Buechler JA \& Yonemoto W. cAMP-dependent protein kinase: framework for a diverse family of regulatory enzymes. Annual Review of Biochemistry 199059 971-1005.

111 Francis SH \& Corbin JD. Structure and function of cyclic nucleotide-dependent protein kinases. Annual Review of Physiology $199456237-272$

112 Hofmann F, Beavo JA, Bechtel PJ \& Krebs EG. Comparison of adenosine $3^{\prime}: 5^{\prime}$-monophosphate-dependent protein kinases from rabbit skeletal and bovine heart muscle. Journal of Biologial Chemistry $19752507795-7801$.

113 Otten AD \& McKnight GS. Overexpression of the type II regulatory subunit of the cAMP-dependent protein kinase eliminates the type I holoenzyme in mouse cells. Journal of Biological Chemistry 1989264 20255-20260.

114 Weber W \& Hilz H. cAMP-dependent protein kinases I and II: divergent turnover of subunits. Biochemistry 198625 56615667.

115 González GA \& Montminy MR. Cyclin AMP stimulates somatostatin gene transcription by phosphorylation of CREB at Ser133. Cell $198959675-680$.

116 Hagiwara M, Brindle P, Harootunian A, Armstrong R, Rivier J, Vale Wet al. Coupling of hormonal stimulation and transcription via the cyclic AMP-responsive factor CREB is rate limited by nuclear entry of protein kinase A. Molecular and Cellular Biology $1993134852-4859$.

117 Armstrong R, Wen W, Meinkoth J, Taylor S \& Montminy M. A refractory phase in cyclic AMP-responsive transcription requires down regulation of protein kinase A. Molecular and Cellular Biology 199515 1826-1832.

118 Van Sande J, Lefort A, Beebe S, Roger P, Perret J, Corbin J et al. Pairs of cyclic AMP analogs, that are specifically synergistic for type I and type II cAMP-dependent protein kinases, mimic 
thyrotropin effects on the function, differentiation expression and mitogenesis of dog thyroid cells. European Journal of Biochemistry 1989183 699-708.

119 Tortora G, Pepe S, Cirafici AM, Ciardiello F, Porcellini A, Clair T et al. Thyroid-stimulating hormone-regulated growth and cell cycle distribution of thyroid cells involve type I isozyme of cyclic AMP-dependent protein kinase. Cell Growth Differentiation 1993 4 359-365.

120 Kupperman E, Wen W \& Meinkoth JL. Inhibition of thyrotropinstimulated DNA synthesis by microinjection of inhibitors of cellular Ras and cyclic AMP-dependent protein kinase. Molecular and Cellular Biology 199313 4477-4484.

121 Damante G \& Di Lauro R. Thyroid-specific gene expression. Biochimica et Biophysica Acta 19941218 255-266.

122 Dremier S, Pohl V, Poteet-Smith C, Roger PP, Corbin J, Doskeland SO et al. Activation of cyclic AMP-dependent kinase is required but may not be sufficient to mimic cyclic AMP-dependent DNA synthesis and thyroglobulin expression in dog thyroid cells. Molecular and Cellular Biology 199717 6717-6726.

123 Gallo A, Benusiglio E, Bonapace IM, Feliciello A, Cassano S, Garbi $\mathrm{C}$ et al. v-ras and protein kinase $\mathrm{C}$ dedifferentiate thyroid cells by down-regulating nuclear cAMP-dependent protein kinase A. Genes and Development 19926 1621-1630.

124 Gallo A, Feliciello A, Varrone A, Cerillo R, Gottesman ME \& Avvedimento VE. Ki-ras oncogene interferes with the expression of cyclic AMP-dependent promoters. Cell Growth and Differentiation $1995691-95$.

125 Feliciello A, Giuliano P, Porcellini A, Garbi C, Obici S, Mele E et al. The v-Ki-Ras oncogene alters cAMP nuclear signaling by regulating the location and the expression of cAMP-dependent protein kinase IIbeta. Journal of Biological Chemistry 1996271 25350-25359.

126 Newton AC. Regulation of protein kinase C. Current Opinion in Cell Biology 19979 161-167.

127 Berridge MJ. Regulation of ion channels by inositol trisphosphate and diacylglycerol. Journal of Experimental Biology 1986124 323-335.

128 Berridge MJ \& Irvine RF. Inositol trisphosphate, a novel second messenger in cellular signal transduction. Nature 1984312 315-321.

129 Fujimoto J \& Brenner-Gati L. Protein kinase-C activation during thyrotropin-stimulated proliferation of rat FRTL-5 thyroid cells. Endocrinology $19921301587-1592$.

130 Ginsberg J, Gupta S, Matowe WC, Kline L \& Brindley DN. Activation of phospholipase D in FRTL-5 thyroid cells by forskolin and dibutyryl-cyclic adenosine monophosphate. Endocrinology $19971383645-3651$

131 Gupta S, Gomez-Muñoz A, Matowe WC, Brindley D \& Ginsberg J. Thyroid-stimulating hormone activates phospholipase D in FRTL5 thyroid cells via stimulation of protein kinase C. Endocrinology $19951363794-3799$.

132 Feliers D \& Pavlovic-Hournac M. Species differences of the thyroid protein kinase C heterogeneity. Thyroid $19944459-465$.

133 Wang XD, Kiang JG \& Smallridge RC. Identification of protein kinase $\mathrm{C}$ and its multiple isoforms in FRTL-5 thyroid cells. Thyroid 19955 137-140.

134 Matowe WC, Gupta S \& Ginsberg J. Regulation of protein kinase $\mathrm{C}$ isoforms in FRTL- 5 thyroid cells by TSH and phorbol ester. Thyroid 19966 53-58.

135 Toker A. Signaling through protein kinase C. Frontiers in Bioscience 19983 D1134-D1147.

136 Lucas M \& Sanchez-Margalet V. Protein kinase C involvement in apoptosis. General Pharmacology 199526 881-887.

137 Bachrach LK, Eggo MC, Mak WW \& Burrow GN. Phorbol esters stimulate growth and inhibit differentiation in cultured thyroid cells. Endocrinology 1985116 1603-1609.

138 Roger PP, Reuse S, Servais P, Van Heuverswyn B \& Dumont JE. Stimulation of cell proliferation and inhibition of differentiation expression by tumor-promoting phorbol esters in dog thyroid cells in primary culture. Cancer Research 198646 898-906.
139 Mori K, Stone S, Braverman LE \& DeVito WJ. Effects of ceramide and protein kinase $\mathrm{C}$ on the regulation of type $\mathrm{I} 5^{\prime}$-deiodinase in FRTL-5 rat thyroid cells. Endocrinology $19961374994-$ 4999.

140 Avvedimento VE, Musti AM, Ueffing M, Obici S, Gallo A, Sanchez $\mathrm{M}$ et al. Reversible inhibition of a thyroid-specific trans-acting factor by Ras. Genes and Development 19915 22-28.

141 Francis-Lang H, Zannini M, De Felice M, Berlingieri MT, Fusco A \& Di Lauro R. Multiple mechanisms of interference between transformation and differentiation in thyroid cells. Molecular and Cellular Biology 199212 5793-800.

142 Igarashi Y \& Kondo Y. Acute effect of thyrotropin on phosphatidylinositol degradation and transient accumulation of diacylglycerol in isolated thyroid follicles. Biochemical and Biophysical Research Communications 198097 759-765.

143 Philp NJ \& Grollman E. Thyrotropin and norepinephrine stimulate the metabolism of phosphoinositides in FRTL-5 thyroid cells. FEBS Letters 1986202 193-196.

144 Rameh LE \& Cantley LC. The role of phosphoinositide 3-kinase lipid products in cell function. Journal of Biological Chemistry $19992748347-8350$.

145 Domin J \& Waterfield MD. Using structure to define the function of phosphoinositide 3-kinase family members. FEBS Letters $199741091-95$.

146 Cantley LC, Auger KR, Carpenter C, Duckworth B, Graziani A, Kapeller R et al. Oncogenes and signal transduction. Cell 1991 64 281-302.

147 Kupperman E, Wofford D, Wen W \& Meinkoth JL. Ras inhibits thyroglobulin expression but not cyclic adenosine monophosphate-mediated signaling in Wistar rat thyrocytes. Endocrinology 1996137 96-104.

148 Ptasznik A, Prossnitz ER, Yoshikawa D, Smrcka A, TraynorKaplan AE \& Bokoch GM. A tyrosine kinase signaling pathway accounts for the majority of phosphatidylinositol 3,4,5-trisphosphate formation in chemoattractant-stimulated human neutrophils. Journal of Biological Chemistry $199627125204-$ 25207.

149 Thelen M \& Didichenko SA. G-protein coupled receptor-mediated activation of PI 3-kinase in neutrophils. Annals of the New York Academy of Sciences 1997832 368-382.

150 Thomason PA, James SR, Casey PJ \& Downes CP. A G-protein beta gamma-subunit-responsive phosphoinositide 3-kinase activity in human platelet cytosol. Journal of Biological Chemistry $199426916525-16528$

151 Jhun BH, Rose DW, Seely BL, Rameh L, Cantley L, Saltiel AR et al. Microinjection of the SH2 domain of the 85-kilodalton subunit of phosphatidylinositol 3-kinase inhibits insulin-induced DNA synthesis and c-fos expression. Molecular and Cellular Biology $1994147466-7475$.

152 McHroy J, Chen D, Wjasow C, Michaeli T \& Backer JM. Specific activation of p85-p110 phosphatidylinositol 3'-kinase stimulates DNA synthesis by Ras- and p70 S6 kinase-dependent pathways. Molecular and Cellular Biology 199717 248-255.

153 Roche S, Koegl M \& Courtneidge SA. The phosphatidylinositol 3-kinase alpha is required for DNA synthesis induced by some, but not all, growth factors. PNAS 199491 9185-9189.

154 Ohsaka Y, Tokumitsu Y \& Nomura Y. Suppression of insulinstimulated phosphatidylinositol 3-kinase activity by the beta3adrenoceptor agonist CL316243 in rat adipocytes. FEBS Letters $1997402246-250$.

155 Scott PH, Belham CM, al-Hafidh J, Chilvers ER, Peacock AJ, Gould GW et al. A regulatory role for CAMP in phosphatidylinositol 3kinase/p70 ribosomal S6 kinase-mediated DNA synthesis in platelet-derived-growth-factor-stimulated bovine airway smoothmuscle cells. Biochemical Journal 1996318 965-971.

156 Alessi DR \& Cohen P. Mechanism of activation and function of protein kinase B. Current Opinion in Genetics and Development $1998855-62$.

157 Cohen P, Alessi DR \& Cross DA. PDK1, one of the missing links in insulin signal transduction? FEBS Letters 1997410 3-10. 
158 Downward J. Lipid-regulated kinases: some common themes at last. Science $1998279673-674$.

159 Bellacosa A, Testa JR, Staal SP \& Tsichlis PN. A retroviral oncogene, akt, encoding a serine-threonine kinase containing an SH2-like region. Science $1991254274-277$.

160 Coffer PJ \& Woodgett JR. Molecular cloning and characterisation of a novel putative protein-serine kinase related to the cAMPdependent and protein kinase $\mathrm{C}$ families. European Journal of Biochemistry 19922051217.

161 Jones PF, Jakubowicz T, Pitossi FJ, Maurer F \& Hemmings BA. Molecular cloning and identification of a serine/threonine protein kinase of the second-messenger subfamily. PNAS 1991 $884171-4175$.

162 Chou MM \& Blenis J. The $70 \mathrm{kDa}$ S6 kinase: regulation of a kinase with multiple roles in mitogenic signalling. Current Opinion in Cell Biology 19957 806-814.

163 Pullen N \& Thomas G. The modular phosphorylation and activation of p70s6k. FEBS Letters $199741078-82$.

164 Chou MM \& Blenis J. The $70 \mathrm{kDa}$ S6 kinase complexes with and is activated by the Rho family $\mathrm{G}$ proteins Cdc42 and Rac1. Cell 199685 573-583.

165 Ridley AJ, Paterson HF, Johnston CL, Diekmann D \& Hall A. The small GTP-binding protein rac regulates growth factor-induced membrane ruffling. Cell 199270 401-410.

166 Rodriguez-Viciana P, Warne PH, Khwaja A, Marte BM, Pappin $\mathrm{D}$, Das $\mathrm{P}$ et al. Role of phosphoinositide $3-\mathrm{OH}$ kinase in cell transformation and control of the actin cytoskeleton by Ras. Cell $199789457-467$.

167 Cass LA \& Meinkoth JL. Differential effects of cyclic adenosine $3^{\prime}, 5^{\prime}$-monophosphate on p70 ribosomal S6 kinase. Endocrinology $19981391991-1998$.

168 Cass LA, Summers SA, Prendergast GV, Backer JM, Birnbaum MJ \& Meinkoth JL. Protein kinase A-dependent and -independent signaling pathways contribute to cyclic AMPstimulated proliferation. Molecular and Cellular Biology 199919 5882-5891.

169 Medina DL, Toro MJ \& Santisteban P. Somatostatin interferes with thyrotropin-induced G1-S transition mediated by PKA and PI3-K: Involvement of RhoA and cyclin E-CDK2 complexes. Journal of Biological Chemistry 2000 275.

170 Malumbres M \& Pellicer A. Ras pathways to cell cycle control and cell transformation. Frontiers in Bioscience $19983887-$ 912.

171 Katz ME \& McCormick F. Signal transduction from multiple Ras effectors. Current Opinion in Genes and Development 19977 7679.

172 Wittinghofer A \& Herrmann C. Ras-effector interactions, the problem of specificity. FEBS Letters $199536952-56$.

173 Bourne HR, Sanders DA \& McCormick F. The GTPase superfamily: a conserved switch for diverse cell functions. Nature 1990 348 125-132.

174 Bos JL. Ras-like GTP-ases. Biochimica et Biophysica Acta 1997 1333 M19-M31.

175 Beug H, Palmieri S, Freudenstein C, Zentgraf H \& Graf T. Hormone-dependent terminal differentiation in vitro of chicken erythroleukemia cells transformed by ts mutants of avian erythroblastosis virus. Cell 198228 907-919.

176 Fiszman MY \& Fuchs P. Temperature-sensitive expression of differentiation in transformed myoblasts. Nature 1975254 429-431.

177 Olson EN, Spizz G \& Tainsky MA. The oncogenic forms of N-ras or H-ras prevent skeletal myoblast differentiation. Molecular and Cellular Biology 19877 2104-2111.

178 Schmidt A, Setoyama C \& de Crombrugghe B. Regulation of a collagen gene promoter by the product of viral mos oncogene. Nature $1985314286-289$.

179 Missero C, Cobellis G, De Felice M \& Di Lauro R. Molecular events involved in differentiation of thyroid follicular cells. Molecular and Cellular Endocrinology $199814037-43$.
180 Velasco JA, Acebron A, Zannini M, Martin-Perez J, Di Lauro R \& Santisteban P. Ha-ras interference with thyroid cell differentiation is associated with a down-regulation of thyroid transcription factor-1 phosphorylation. Endocrinology 1998139 2796-2802.

181 Miller MJ, Rioux L, Prendergast GV, Cannon S, White MA \& Meinkoth JL. Differential effects of protein kinase A on Ras effector pathways. Molecular and Cellular Biology 199818 $3718-3726$

182 al-Alawi N, Rose DW, Buckmaster C, Ahn N, Rapp U, Meinkoth J et al. Thyrotropin-induced mitogenesis is Ras dependent but appears to bypass the Raf-dependent cytoplasmic kinase cascade. Molecular and Cellular Biology 199515 1162-1168.

183 Hafner S, Adler HS, Mischak H, Janosch P, Heidecker G, Wolfman A et al. Mechanism of inhibition of Raf- 1 by protein kinase A. Molecular and Cellular Biology 199414 6696-6703.

184 Lamy F, Wilkin F, Baptist M, Posada J, Roger PP \& Dumont JE. Phosphorylation of mitogen-activated protein kinases is involved in the epidermal growth factor and phorbol ester, but not in the thyrotropin/cAMP, thyroid mitogenic pathway. Journal of Biological Chemistry 1993268 8398-8401.

185 White MA, Nicolette C, Minden A, Polverino A, Van Aelst L, Karin $\mathrm{M}$ et al. Multiple Ras functions can contribute to mammalian cell transformation. Cell 199580 533-541.

186 Ramocki MB, White MA, Konieczny SF \& Taparowsky EJ. A role for RalGDS and a novel Ras effector in the Ras-mediated inhibition of skeletal myogenesis. Journal of Biological Chemistry $199827317696-17701$.

187 Matsubara K, Kishida S, Matsuura Y, Kitayama H, Noda M \& Kikuchi A. Plasma membrane recruitment of RalGDS is critical for Ras-dependent Ral activation. Oncogene 199918 13031312.

188 Urano T, Emkey R \& Feig LA. Ral-GTPases mediate a distinct downstream signaling pathway from Ras that facilitates cellular transformation. EMBO Journal 199615 810-816.

189 White MA, Vale T, Camonis JH, Schaefer E \& Wigler MH. A role for the Ral guanine nucleotide dissociation stimulator in mediating Ras-induced transformation. Journal of Biological Chemistry 1996271 16439-16442.

190 Miller MJ, Prigent S, Kupperman E, Rioux L, Park SH, Feramisco JR et al. RalGDS functions in Ras- and cAMP-mediated growth stimulation. Journal of Biological Chemistry 1997272 56005605.

191 Altschuler DL, Peterson SN, Ostrowski MC \& Lapetina EG. Cyclic AMP-dependent activation of Rap1b. Journal of Biological Chemistry $199527010373-10376$.

192 Dremier S, Vandeput F, Zwartkruis FJT, Bos JL, Dumont JE et al. Activation of the small $G$ protein Rap1 in dog thyroid cells by both cAMP-dependent and -independent pathways. Biochemical and Biophysical Research Communications 2000267 7-11.

193 Yoshida Y, Kawata M, Miura Y, Musha T, Sasaki T, Kikuchi A et al. Microinjection of smg/rap1/Krev-1 p21 into Swiss 3T3 cells induces DNA synthesis and morphological changes. Molecular and Cellular Biology 199212 3407-3414.

194 Wu J, Dent P, Jelinek T, Wolfman A, Weber MJ \& Sturgill TW. Inhibition of the EGF-activated MAP kinase signaling pathway by adenosine 3',5'-monophosphate. Science $19932621065-$ 1069.

195 Cook SJ \& McCormick F. Inhibition by cAMP of Ras-dependent activation of Raf. Science 1993262 1069-1072.

196 Sevetson BR, Kong X \& Lawrence JC Jr. Increasing cAMP attenuates activation of mitogen-activated protein kinase. PNAS $19939010305-10309$.

197 Cook SJ, Rubinfeld B, Albert I \& McCormick F. RapV12 antagonizes Ras-dependent activation of ERK1 and ERK2 by LPA and EGF in Rat-1 fibroblasts. EMBO Journal 199312 34753485 .

198 de Rooij J, Zwartkruis FJ, Verheijen MH, Cool RH, Nijman SM, Wittinghofer A et al. Epac is a Rap1 guanine-nucleotideexchange factor directly activated by cyclic AMP. Nature 1998 $396474-477$. 
199 Kawasaki H, Springett GM, Mochizuki N, Toki S, Nakaya M, Matsuda $\mathrm{M}$ et al. A family of cAMP-binding proteins that directly activate Rap-1. Science 1998282 2275-2279.

200 Van Aelst L \& D'Souza-Schorey C. Rho GTPases and signaling networks. Genes and Development 199711 2295-2322.

201 Kozma R, Ahmed S, Best A \& Lim L. The Ras-related protein $\mathrm{Cdc} 42 \mathrm{Hs}$ and bradykinin promote formation of peripheral actin microspikes and filopodia in Swiss 3T3 fibroblasts. Molecular and Cellular Biology $1995151942-1952$.

202 Nobes CD \& Hall A. Rho, rac, and cdc42 GTPases regulate the assembly of multimolecular focal complexes associated with actin stress fibers, lamellipodia, and filopodia. Cell $19958153-$ 62.

203 Olson MF, Ashworth A \& Hall A. An essential role for Rho, Rac, and Cdc42 GTPases in cell cycle progression through G1. Science $19952691270-1272$.

204 Seger R \& Krebs EG. The MAPK signaling cascade. FASEB Journa $19959726-735$

205 Hill CS, Wynne J \& Treisman R. The Rho family GTPases RhoA, Rac1, and CDC42Hs regulate transcriptional activation by SRF. Cell 199581 1159-1170.

206 Khosravi FR, Solski PA, Clark GJ, Kinch MS \& Der CJ. Activation of Rac1, RhoA, and mitogen-activated protein kinases is required for Ras transformation. Molecular and Cellular Biology $1995156443-6453$.

207 Qiu RG, Chen J, Kirn D, McCormick F \& Symons M. An essential role for Rac in Ras transformation. Nature 1995374 457-459.

208 Qiu RG, Chen J, McCormick F \& Symons M. A role for Rho in Ras transformation. PNAS 199592 11781-11785.

209 Qiu RG, Abo A, McCormick F \& Symons M. Cdc42 regulates anchorage-independent growth and is necessary for Ras transformation. Molecular and Cellular Biology 199717 34493458.

210 Lin R, Bagrodia S, Cerione R \& Manor D. A novel Cdc42Hs mutant induces cellular transformation. Current Biology 19977 794-797.

211 Ridley AJ \& Hall A. The small GTP-binding protein rho regulates the assembly of focal adhesions and actin stress fibers in response to growth factors. Cell $199270389-399$.

212 Lang P, Gesbert F, Delespine-Carmagnat M, Stancou R, Pouchelet M \& Bertoglio J. Protein kinase A phosphorylation of RhoA mediates the morphological and functional effects of cyclic AMP in cytotoxic lymphocytes. EMBO Journal 199615 510-519.

213 Dong JM, Leung T, Manser E \& Lim L. cAMP-induced morphological changes are counteracted by the activated RhoA small GTPase and the Rho kinase ROKalpha. Journal of Biological Chemistry $199827322554-22562$.

214 Noguchi Y, Nakamura S, Yasuda T, Kitagawa M, Kohn LD, Saito Y et al. Newly synthesized Rho A, not Ras, is isoprenylated and translocated to membranes coincident with progression of the G1 to S phase of growth-stimulated rat FRTL-5 cells. Journal of Biological Chemistry 1998273 3649-3653.

215 Chin DJ, Gil G, Russell DW, Liscum L, Luskey KL, Basu SK et al. Nucleotide sequence of 3-hydroxy-3-methyl-glutaryl coenzyme A reductase, a glycoprotein of endoplasmic reticulum. Nature 1984308 613-617.

216 Grieco D, Beg ZH, Romano A, Bifulco M \& Aloj SM. Cel cycle progression and 3-hydroxy-3-methylglutaryl coenzyme A reductase are regulated by thyrotropin in FRTL-5 rat thyroid cells. Journal of Biological Chemistry $199026519343-$ 19350.

217 Bifulco M, Perillo B, Saji M, Laezza C, Tedesco I, Kohn LD et al. Regulation of 3-hydroxy-3-methylglutaryl coenzyme A reductase gene expression in FRTL-5 cells. I. Identification and characterization of a cyclic AMP-responsive element in the rat reductase promoter. Journal of Biological Chemistry 1995270 15231-15236.

218 Jullien-Flores V, Dorseuil O, Romero F, Letourneur F, Saragosti S, Berger R et al. Bridging Ral GTPase to Rho pathways. Journal of Biological Chemistry $199527022473-22477$.
219 Sherr CJ. G1 phase progression: Cycling on cue. Cell 199479 $551-555$

220 Ohtsubo M \& Roberts JM. Cyclin-dependent regulation of G1 in mammalian fibroblasts. Science 1993259 1908-1912.

221 Quelle DE, Ashmun RA, Shurtleff SA, Kato JY, Bar-Sagi D, Roussel MF et al. Overexpression of mouse D-type cyclins accelerates G1 phase in rodent fibroblasts. Genes and Development 1993 7 1559-1571.

222 Resnitzky D, Gossen M, Bujard H \& Reed SI. Acceleration of the G1/S phase transition by expression of cyclins D1 and E with an inducible system. Molecular and Cellular Biology 199414 16691679.

223 Matsushime H, Roussel MF \& Sherr CJ. Novel mammalian cyclins (CYL genes) expressed during G1. Cold Spring Harbor Symposium Quantitative Biology 199156 69-74.

224 Matsushime H, Roussel MF, Ashmun RA \& Sherr CJ. Colonystimulating factor 1 regulates novel cyclins during the $\mathrm{G} 1$ phase of the cell cycle. Cell $199165701-713$

225 Matsushime H, Ewen ME, Strom DK, Kato JY, Hanks SK, Roussel MF et al. Identification and properties of an atypical catalytic subunit (p34PSK-J3/cdk4) for mammalian D type G1 cyclins. Cell 199271 323-334.

226 Kerkhoff E \& Rapp UR. Induction of cell proliferation in quiescent NIH 3T3 cells by oncogenic c-Raf-1. Molecular and Cellular Biology 199717 2576-2586.

227 Weber JD, Raben DM, Phillips PJ \& Baldassare JJ. Sustained activation of extracellular-signal-regulated kinase 1 (ERK1) is required for the continued expression of cyclin D1 in G1 phase. Biochemical Journal 1997326 61-68.

228 Peeper DS, Upton TM, Ladha MH, Neuman E, Zalvide J, Bernards $\mathrm{R}$ et al. Ras signalling linked to the cell-cycle machinery by the retinoblastoma protein. Nature 1997386 177-181.

229 Cheng M, Sexl V, Sherr CJ \& Roussel MF. Assembly of cyclin D-dependent kinase and titration of $\mathrm{p} 27 \mathrm{Kip} 1$ regulated by mitogen-activated protein kinase kinase (MEK1). PNAS 199895 1091-1096.

230 Diehl JA, Cheng M, Roussel MF \& Sherr CJ. Glycogen synthase kinase-3beta regulates cyclin D1 proteolysis and subcellular localization. Genes and Development 199812 3499-3511.

231 Dowdy SF, Hinds PW, Louie K, Reed SI, Arnold A \& Weinberg RA. Physical interaction of the retinoblastoma protein with human D cyclins. Cell 199373 499-511.

232 Ewen ME, Sluss HK, Sherr CJ, Matsushime H, Kato J \& Livingston DM. Functional interactions of the retinoblastoma protein with mammalian D-type cyclins. Cell 199373 487-497.

233 Kato J, Matsushime H. Hiebert SW, Ewen ME \& Sherr CJ. Direct binding of cyclin D to the retinoblastoma gene product (pRb) and pRb phosphorylation by the cyclin D-dependent kinase CDK4. Genes and Development 19937 331-342.

234 Matsushime H, Quelle DE, Shurtleff SA, Shibuya M, Sherr CJ \& Kato JY. D-type cyclin-dependent kinase activity in mammalian cells. Molecular and Cellular Biology 199414 2066-2076.

235 Meyerson M \& Harlow E. Identification of G1 kinase activity for cdk6, a novel cyclin D partner. Molecular and Cellular Biology $1994142077-2086$.

236 Nevins JR. E2F: a link between the Rb tumor suppressor protein and viral oncoproteins. Science 1992258 424-429.

237 Koff A, Giordano A, Desai D, Yamashita K, Harper JW, Elledge S et al. Formation and activation of a cyclin E-cdk 2 complex during the G1 phase of the human cell cycle. Science $19922571689-$ 1694.

238 Dulic V, Lees E \& Reed SI. Association of human cyclin E with a periodic G1-S phase protein kinase. Science 1992257 19581961.

239 Hinds PW, Mittnacht S, Dulic V, Arnold A, Reed SI \& Weinberg RA. Regulation of retinoblastoma protein functions by ectopic expression of human cyclins. Cell 199270 993-1006.

240 Hatakeyama M, Brill JA. Fink GR \& Weinberg RA. Collaboration of G1 cyclins in the functional inactivation of the retinoblastoma protein. Genes and Development 19948 1759-1771. 
241 Mittnacht S, Lees JA, Desai D, Harlow E, Morgan DO \& Weinberg RA. Distinct sub-populations of the retinoblastoma protein show a distinct pattern of phosphorylation. EMBO Journal 199413 118-127.

242 Kelly BL, Wolfe KG \& Roberts JM. Identification of a substratetargeting domain in cyclin E necessary for phosphorylation of the retinoblastoma protein. PNAS 199895 2535-2540.

243 Lundberg AS \& Weinberg RA. Functional inactivation of the retinoblastoma protein requires sequential modification by at least two distinct cyclin-cdk complexes. Molecular and Cellular Biology 199818 753-761.

244 Sheaff RJ, Groudine M, Gordon M, Roberts JM \& Clurman BE. Cyclin E-CDK2 is a regulator of p27Kip1. Genes and Development 199711 1464-1478.

245 Vlach J, Hennecke S \& Amati B. Phosphorylation-dependent degradation of the cyclin-dependent kinase inhibitor p27. EMBO Journal 199716 5334-5344.

246 Blow JJ \& Nurse P. A cdc2-like protein is involved in the initiation of DNA replication in Xenopus egg extracts. Cell $199062855-$ 862 .

247 D'Urso G, Marraccino RL, Marshak DR \& Roberts JM. Cell cycle control of DNA replication by a homologue from human cells of the p34cdc2 protein kinase. Science 1990250 786-791.

248 Fang F \& Newport JW. Evidence that the G1-S and G2-M transitions are controlled by different cdc2 proteins in higher eukaryotes. Cell 199166 731-742.

249 Stillman B. Cell cycle control of DNA replication. Science 1996 274 1659-1664.

250 Krude T, Jackman M, Pines J \& Laskey RA. Cyclin/Cdk-dependent initiation of DNA replication in a human cell-free system. Cell 199788 109-119.

251 Zhao J, Dynlacht B, Imai T, Hori T \& Harlow E. Expression of NPAT, a novel substrate of cyclin E-CDK2, promotes S-phase entry. Genes and Development 199812 456-461.

252 Fisher RP \& Morgan DO. A novel cyclin associates with MO15/ CDK7 to form the CDK-activating kinase. Cell $199478713-$ 724 .

253 Yamamoto K, Hirai A, Ban T, Saito J, Tahara K, Terano T et al Thyrotropin induces G1 cyclin expression and accelerates G1 phase after insulin-like growth factor I stimulation in FRTL-5 cells. Endocrinology 1996137 2036-2042.

254 Hirai A, Nakamura S, Noguchi Y, Yasuda T, Kitagawa M, Tatsuno I et al. Geranylgeranylated rho small GTPase(s) are essential for the degradation of $\mathrm{p} 27 \mathrm{Kip} 1$ and facilitate the progression from $\mathrm{G} 1$ to $\mathrm{S}$ phase in growth-stimulated rat FRTL-5 cells. Journal of Biological Chemistry 1997272 13-16.
255 Reynisdóttir I, Polyak K, Iavarone A \& Massagué J. Kip/Cip and Ink4 cdk inhibitors cooperate to induce cell cycle arrest in response to TGF-b. Genes and Development $199591831-$ 1845.

256 Zhang H, Hannon GJ \& Beach D. p21-containing cyclin kinases exist in both active and inactive states. Genes and Development 19948 1750-1758.

257 Sherr CJ \& Roberts JM. Inhibitors of mammalian G1 cyclindependent kinases. Genes and Development 19959 11491163.

258 Winston J, Dong F \& Pledger WJ. Differential modulation of G1 cyclins and the Cdk inhibitor p27kip1 by platelet-derived growth factor and plasma factors in density-arrested fibroblasts. Journal of Biological Chemistry 1996271 11253-11260.

259 Nourse J, Firpo E, Flanagan WM, Coats S, Polyak K, Lee MH et al. Interleukin-2-mediated elimination of the p27Kip1 cyclindependent kinase inhibitor prevented by rapamycin. Nature 1994372 570-573.

260 Firpo EJ, Koff A, Solomon MJ \& Roberts JM. Inactivation of a Cdk2 inhibitor during interleukin 2-induced proliferation of human T lymphocytes. Molecular and Cellular Biology 199414 4889-4901.

261 Kato JY, Matsuoka M, Polyak K, Massague J \& Sherr CJ. Cyclic AMP-induced G1 phase arrest mediated by an inhibitor (p27Kip1) of cyclin-dependent kinase 4 activation. Cell 1994 79 487-496.

262 Pagano M, Tam SW, Theodoras AM, Beer-Romero P, Del Sal G, Chau $\mathrm{V}$ et al. Role of the ubiquitin-proteasome pathway in regulating abundance of the cyclin-dependent kinase inhibitor p27. Science $1995269682-685$.

263 Coats S, Flanagan WM, Nourse J \& Roberts JM. Requirement of p27Kip1 for restriction point control of the fibroblast cell cycle. Science $1996272877-880$.

264 Rivard N, L'Allemain G, Bartek J \& Pouyssegur J. Abrogation of p27Kip1 by cDNA antisense suppresses quiescence (Go state) in fibroblasts. Journal of Biological Chemistry 1996271 1833718341.

265 Weber JD, Cheng J, Raben DM, Gardner A \& Baldassare JJ. Ablation of Go alpha overrides G1 restriction point control through Ras/ERK/cyclin D1-CDK activities. Journal of Biological Chemistry 1997272 17320-17326.

Received 4 January 2000

Accepted 7 March 2000 